NBER WORKING PAPER SERIES

\author{
ARE BROTHERS REALLY BETTER? \\ SIBLING SEX COMPOSITION AND \\ EDUCATIONAL ACHIEVEMENT REVISITED
}

Robert Kaestner

Working Paper 5521

\author{
NATIONAL BUREAU OF ECONOMIC RESEARCH \\ 1050 Massachusetts Avenue \\ Cambridge, MA 02138 \\ April 1996
}

The author is grateful to Ted Joyce, Sanders Korenman and two anonymous referees for their helpful comments. This paper is part of NBER's research program in Labor Studies. Any opinions expressed are those of the author and not those of the National Bureau of Economic Research.

(c) 1996 by Robert Kaestner. All rights reserved. Short sections of text, not to exceed two paragraphs, may be quoted without explicit permission provided that full credit, including $\odot$ notice, is given to the source. 


\title{
ARE BROTHERS REALLY BETTER? \\ SIBLING SEX COMPOSITION AND \\ EDUCATIONAL ACHIEVEMENT REVISITED
}

\begin{abstract}
In this paper, I examine the relationship between sibling sex composition and educational achievement. First, I replicate the study of Butcher and Case (1994) using data on a more recent birth cohort. Contrary to the findings of that study, I find basically no effect of sibling sex composition on the educational attainment of white males or females, although among black adults, those who grew up with a sister, or who had relatively more sisters, had greater levels of educational attainment than persons with no or fewer sisters. Second, I broaden the analysis by examining the educational outcomes of children and teenagers. This extension is important because it provides an additional opportunity to test for sibling sex composition effects, and it helps differentiate between potential causes of a sibling sex composition effect. The results obtained from the analysis of child and teen outcomes suggest that sibling sex composition had little effect on educational achievement. The only group to be affected was black teens between the ages of 15 and 18. Those who grew up with sisters had higher educational achievement levels than those who grew up with brothers.
\end{abstract}

\author{
Robert Kaestner \\ National Bureau of Economic Research \\ 50 East 42nd Street, 17th Floor \\ New York, NY 10017-5405 \\ and NBER
}




\section{Introduction}

In a recent article, Butcher and Case (1994) investigate the effect of sibling sex composition on the educational attainment of men and women born between the years 1920 and 1961 . Their resuits indicate that sibling sex composition had no effect on the educational attainment of men, but among women, those who grew up in households with a sister obtained less education than women raised only with brothers. Butcher and Case (1994) also present evidence that the impact of sibling sex composition on the educational attainment of women has decreased over time.

The Butcher and Case (1994) study is interesting because it identifies a common, but previously overlooked determinant of educational attainment.' It is important because of the significant role that education plays in determining economic well being. This is particularly true today, given the large, by historical standards, economic disparities between persons with and without a post secondary education. The public policy relevance of the study, however, is not obvious, and depends on the nature of the underlying cause of the sibling sex composition effect. Butcher and Case (1994) offer two possible reasons why sibling sex composition may influence educational attainment. One explanation focuses on intrafamily resource allocations and the other on child gender role development and gender related classroom biases. If the underlying cause of the sibling sex composition effect is because families allocate resources differently depending on sibling sex composition, then there is not much scope for policy intervention. Households are simply making optimal resource allocations given prices and preferences, and there is no reason to expect a market failure. ${ }^{2}$ On the other hand, if the cause of the effect is that success in school depends on the amount of a particular gender-

\footnotetext{
'Powell and Steelman (1989) examine whether sibling sex composition affects parents' contribution to a child's college education. These authors found that an additional brother in the family reduces the probability that parents contribute to their daughters education by approximately 5 percentage points. ${ }^{2}$ This statement may be incorrect if, for example, there is gender discrimination in the labor market and households allocate resources within the family based on market determined rates of return. Similarly, capital market imperfections may affect intrafamily resource allocations. In both cases, however, the source of the market failure is outside the family, and public policies to address these
} 
determined trait a person exhibits, then an appropriate intervention can be devised to correct the problem. Based on their findings, Butcher and Case (1994) tend to emphasize the gender role and school-based explanation of the sibling sex composition effect.

The purpose of this study is to re-examine the relationship between sibling sex composition and educational achievement. Toward this end, I obtain empirical estimates of the effect of sibling sex composition on child and teen educational achievement, and the educational attainment of adults. Examining the educational outcomes of school-age children is important for two reasons. First, examining child and teen educational outcomes provides an additional test of whether sibling sex composition affects educational achievement since both explanations of the sibling sex composition effect cited above, are relevant to child and teen educational achievement. Families clearly make investments in the education of their school age children. Furthermore, human capital investments are durable, and the stock of human capital may affect the marginal product and cost of future human capital investments. ${ }^{3}$ These considerations suggest that differences in intrafamily resource allocations caused by different family configurations would appear early in life and have long lasting effects. Thus, the effect of sibling sex composition on educational achievement would be revealed during child and teen years, and the analysis of child and teen educational outcomes provides a test of whether there is in fact a sibling sex composition effect. Second, if the sibling sex composition effect is a result of gender role development and biased classroom instruction, as suggested by Butcher and Case (1994), then we would necessarily expect the educational achievement of school-age children to be affected by the sibling sex composition of their family. An analysis of child and teen educational outcomes will reveal at what age, if any, the effect of sibling sex composition becomes evident. The absence of a significant relationship between sibling sex composition and child and teen educational achievement is strong evidence against the classroom instruction

issues would not focus on the family.

${ }^{3}$ It seems reasonable to assume that the stock of human capital affects the marginal product of human capital investments. For example, formal schooling at age 16 is more effective if the child received schooling prior to this period. 
hypothesis. On the other hand, a significant correlation between child educational achievement and sibling sex composition is consistent with both hypotheses.

Another contribution of the paper is the use of a more recent cohort of adults to examine the relationship between sibling sex composition and educational attainment. As noted above, Butcher and Case (1994) find generational differences in the effect of sibling sex composition on educational attainment. The presence of sisters in a household reduced the educational attainment of women born between the years 1920 and 1940 more than it did for women born between 1941 and 1961. In this paper, I examine the effect of sibling sex composition on the educational attainment of individuals born between the years 1958 to 1965 . The use of a more recent birth cohort will reveal whether the generational differences observed by Butcher and Case (1994) continue to progress in a predictable way, namely that the presence of sisters has less of an adverse effect on educational attainment of women born in more recent periods. Finally, this paper also extends the previous analysis by examining the relationship between sibling sex composition and educational achievement for non-whites.

In summary, in this paper I investigate whether sibling sex composition affects child, teen and adult educational achievement (e.g., attainment). This comprehensive approach to the problem will provide evidence as to the existence of a sibling sex composition effect on educational achievement and furnish limited evidence as to the underlying cause of such a relationship if it is in fact found. The results suggest that for most groups examined in this paper, sibling sex composition had little effect on educational achievement. The two groups for which sibling sex composition did matter was black teenagers between the ages of 15 and 18 and black adults. For these groups, individuals (males and females) who grew up with a sister, or who had relatively more sisters, had higher levels of educational achievement than persons with no or fewer sisters. 


\section{Potential Explanations of the Sibling Sex Composition Effect}

\section{A. Intrafamily Allocation of Resources}

According to models of the family developed by Becker and Tomes $(1976,1986)$ and Becker (1991), parents care about the welfare of their children and as a result, finance human capital investments in their children. In the absence of credit constraints and preferences for equality of earnings, investments in children are made until the return to additional investment equals the market rate of interest. If , however, a family is relatively poor and does not have access to sufficient funds to finance this optimal level of investment, resources are allocated according to rates of return on the investments. For example, if the rate of return on educational investments is greater for male children than female children, males will receive more of such investments and consequently have higher levels of educational attainment than females. As Butcher and Case (1994) note, these circumstances can lead to a systematic relationship between sibling sex composition and educational attainment. In families with only female children, each daughter would receive more resources than a daughter in a similar family that had male children. Similarly, in families with only male children, each son would receive less resources than a son in a family that had female children. In addition, these considerations suggest that the more financially constrained the family is, the more likely it is to observe a sibling sex composition effect. Thus, two empirical tests of this explanation of the sibling sex composition effect are to examine whether educational achievement and educational attainment are correlated with the percentage of female children in the family, holding constant family income, and whether this correlation differs by the amount of family resources. ${ }^{4}$

In contrast to Becker and Tomes $(1976,1986)$, Berhman et al. (1982) suggest that parents care about two aspects of their children's well-being: lifetime wealth and market earnings. These authors assume that parents have an aversion to inequality of earnings among their children, and as a result, parents do not simply 
allocate resources on the basis of the returns to human capital investments, but also with reference to earnings equality. Therefore, children whose return on investment is low, and who have siblings whose return on investment is high, will receive more resources than similar children without such siblings. Butcher and Case (1994) refer to this argument, and suggest that if male children are those with high rates of return, and female children those with low rates of return, then female children who grow up with brothers will receive more resources than similar female children without brothers. These results suggest that the presence of a brother will be positively correlated with the educational achievement of females. Similarly, the presence of a sister will be negatively correlated with the educational achievement of males. Moreover, these theoretical considerations would suggest that any observed effect of sibling sex composition would diminish over time as the rate of return to human capital investments becomes more equal for men and women. ${ }^{5}$

Recently, however, Berhman et al. (1994) presented evidence indicating that parents do not have a strong aversion to earnings inequality and invest in children in ways that reinforce differences in innate abilities that influence earnings. Analogous reasoning suggests that parents may also invest in such a way as to reinforce differences in social environmental factors that influence earnings. ${ }^{6}$ Thus, if environmental factors such as labor market discrimination favor males, the presence of a brother will be negatively correlated with the educational achievement of females, and the presence of a sister positively correlated with the educational achievement of males.

Another way that sibling sex composition may affect educational outcomes is suggested by the work of Thomas (1994). Thomas (1994) presented empirical evidence related to child height that implies that mothers allocate more resources to female children, and that fathers allocate more resources to male children.

\footnotetext{
${ }^{4}$ Butcher and Case (1994) implement only the first of these tests.

5 This point may explain why Butcher and Case (1994) find a diminished effect of sibling sex composition over time for women, but it is inconsistent with their findings of an insignificant effect of sibling sex composition on male educational attainment.

${ }^{6}$ Examples of the types of social environmental factors I have in mind are gender discrimination in the
} 
According to Thomas (1994), the primary reason for these gender specific preferences is that the rate of return to investments differ by the gender of the child and the gender of the parent. A mother's investment in her daughter has a greater benefit than her investment in her son because the mother has a longer and closer relationship with her daughter than her son. These differential preferences are exacerbated by the technology of child rearing that are related to gender: mothers spend more time raising female children and fathers more time raising male children. The upshot is that daughters of a female headed household will receive more resources if there are brothers in the family than if there are only sisters. ${ }^{7}$ Empirically, we would expect to observe a positive correlation between the presence of a brother and female educational achievement in female headed households. Analogous reasoning would suggest that there would be a negative correlation between the presence of a sister and male educational achievement. This discussion demonstrates the need to obtain separate estimates of the effect of sibling sex composition by family structure.

Finally, a sibling sex composition effect may arise if there is a parental preference for children of a particular sex. For example, in the United States there is some evidence that black women prefer daughters since the birth interval between the first and second born is smaller if the first born was a boy than if it was a girl (Teachman and Schollaert 1989). Similarly, if there is a preference for boys, the birth interval between the first and second born will be smaller if the first born was a girl. Shorter birth intervals adversely affect the child's endowment (e.g., health), and possibly the rate of return on future human capital investments (Rosenzweig 1986). Thus, the timing between births may be correlated with both educational achievement and sibling sex composition. Failure to adequately control for the timing of births may lead to a spurious correlation between sibling sex composition and educational achievement.

As this selective review of the relevant theory suggests, there are several ways that sibling sex composition may affect intrafamily resource allocations and ultimately educational achievement. Also obvious

labor market, and specialization in household production that takes place through the marriage market. 
from this review is that the sign of the effect of sibling sex composition is theoretically ambiguous. For example, the presence of sisters may have a positive or negative effect on the educational achievement of females. Therefore, it is difficult to derive a testable hypothesis that can differentiate between various mechanisms of intrafamily resource allocations that may underlie a sibling sex composition effect. As a result, empirical analyses such as the current one, and that of Butcher and Case (1994), are limited to testing whether there in fact is a sibling sex composition effect.

Butcher and Case (1994) test the intrafamily resource allocation hypothesis by estimating models of educational attainment that alternately include an indicator of the presence of sisters, an indicator of the presence of brothers, and a variable measuring the percentage of female children. The authors' results indicate that the presence of sisters reduces the educational attainment of women, but not men. Based on their findings, Butcher and Case (1994) reject explanations of the sibling sex composition effect based on conventional economic models of the family. ${ }^{8}$

Butcher and Case (1994) do, however, offer a less traditional explanation in which intrafamily resource allocation plays a role. They speculate that “... the presence of any sisters reduces education for women, perhaps because it changes the parents' educational goals for their daughters and thus the family resources allorted to daughters' educations" (p. 552). Basically, Butcher and Case (1994) are suggesting that sibling sex composition alters parents' preferences. Either it causes parents to alter their preferences for equality of child outcomes, or it causes them to change the relative weight placed on child outcomes in their objective function. ${ }^{9}$ Both of these explanations, however, conflict with the reported results. The finding that the presence of a sister

${ }^{7}$ I am defining female headed households as the absence of a father.

8 Butcher and Case (1994) note that their findings are not consistent with the simple models of the family described in the text, although the brief theoretical discussion is not exhaustive. Furthermore, Butcher and Case (1994) did not consider all of the empirical tests implied by the somewhat more extensive review of the literature included in the text.

"The latter mechanism is referred to as "child concern" in the literature (Becker 1991, Berhman, Pollak and Taubman 1982). 
reduces the educational attainment of women may imply that parental preferences for inequality of outcomes are reduced when there is another daughter in the family. ${ }^{10}$ The parents may care only about the equality of outcomes within gender when there is more than one child with the same sex. This model also predicts, however, that a boy in a family with two sisters would receive more resources than a boy in a family with one sister and one brother. This prediction is inconsistent with results in Table IV of Butcher and Case (1994). The second possibility, that sibling sex composition affects parents "concern" for children of a particular sex, was mentioned by Butcher and Case (1994) in their discussion of children as a scarce commodity. Children from families in which they are the only son or daughter may be considered a scarce good, and be valued more highly than similar children with other siblings of the same sex. As Butcher and Case (1994) note, however, their results are inconsistent with this hypothesis since the educational achievement of males with no brothers is not significantly different from the educational achievement of males with brothers.

\section{B. Reference Groups and Gender Bias in Schools}

Butcher and Case (1994) offer an alternative explanation of the sibling sex composition effect that focuses on schools and classroom instruction. In this explanation, sibling sex composition and educational achievement are correlated because differences in sibling sex composition result in differences in the amount of a particular gender specific trait that children acquire. Learning is partly determined by this gender specific trait because of how it affects individual motivation or because of biases in classroom instruction which favor children with this trait. The sibship is important in this explanation because it is the child's "reference group" and the child adopts the traits of their siblings.

As an illustrative example, Butcher and Case (1994) cite the findings of an American Association of University Women (AAUW 1992) study. The authors of this study assert that boys have a tendency to engage

\footnotetext{
${ }^{10}$ Implicit in this argument is that boys have higher marginal returns to education than girls, and that endowments are equal.
} 
in more investigatory and experimental activities than girls, and note that schools may exacerbate this difference by the way classroom instruction is organized. Under these circumstances, girls with brothers may adopt some of the brother's traits and receive a more complete education than a girl without brothers. The AAUW (1992) scenario, however, is only one of many possible ways that the sibship might affect a child's motivation and learning. For example, young girls score higher on achievement tests than boys. "Thus, the presence of relatively high achieving sisters may result in greater educational achievement of both boys and girls if siblings are an important input into the educational production function (Zajonc 1976). In summary, the "reference group" theory does not yield an unambiguous prediction as to how sisters or brothers in the sibship will affect educational achievement. What is clear, however, is that the most appropriate way to test this explanation of the sibling sex composition effect is to examine the educational achievement of school age children. If the "reference group" explanation is valid, then the educational outcomes of school age children are necessarily affected. Adult educational outcomes (e.g., years of completed education) may be affected if these outcomes are dependent on prior educational achievement.

Butcher and Case (1994) tested the "reference group" explanation of the sibling sex composition effect by examining the relationship between adult educational attainment and a variable measuring the presence of sisters. While the "reference group" explanation of the sibling sex composition effect may apply to adult educational attainment, a more direct test is to examine educational achievement of school age children. In addition, it is also unclear why a variable measuring the presence of a sister, as opposed to a variable measuring the presence of an older sister is the appropriate measure of sibling sex composition. Indeed, Butcher and Case (1994) suggest at one point that it is the sibling sex composition of older siblings that is important. ${ }^{12}$ If the older siblings are important inputs into the human capital production function of younger

\footnotetext{
"For example, reading scores of children in the NLSY are significantly higher for girls than boys at every age between 7 and 13. Math scores do not differ significantly between girls and boys, although girls have higher average scores until age 12 .

${ }^{12}$ Butcher and Case (1994) report that in analyses not presented, they found that the presence of an
} 
siblings as suggested by Zajonc (1976), then the relevant variable is the sex composition of older siblings. ${ }^{13}$

As noted previously, Butcher and Case (1994) conclude that their results are most consistent with the "reference group" explanation of the sibling sex composition effect. Their primary reason for this conclusion is the asymmetry of the effects of sibling sex composition on educational attainment of men and women.

Sibling sex composition affects female, but not male, educational attainment.

\section{Empirical Strategy}

In order to test whether sibling sex composition affects educational achievement, several ordinary least squares regression models will be estimated. The basic model consists of regressing sibling sex composition on a measure of educational achievement, holding constant family size, family resources, family background characteristics and person specific attributes. As the discussion of the potential explanations of a sibling sex composition effect suggests, sibling sex composition should be measured in a variety of ways: as the percentage of female children, by an indicator of the presence of sisters, and by an indicator of the presence of brothers. In addition, the sibling sex composition variables should also be constructed using only older siblings.

In addition to the basic regression models, several alternative specifications will be tested. First, the sibling sex composition variable will be interacted with a measure of family resources to test whether the sibling sex composition effect becomes more evident as family resources become more constrained. If intrafamily resource allocations are the cause of a sibling sex composition effect, then the effect should be more evident among families with less resources. Second, a separate set of analyses will be carried out using a sample of persons from female headed households to test whether gender-specific parental preferences for children result in a sibling sex composition effect. Finally, the basic model will be re-estimated including

older brother in "a nearby age range" did not affect the educational attainment of women. This, however, is a limited test of the hypothesis under consideration.

${ }^{13}$ A referee also pointed out that the sibling sex composition of older siblings may be the relevant measure because of how information about the true returns to human capital investments is transmitted. 
measures of birth spacing to control for possible confounding effects of the timing of births.

IV. Data

The data used in this study are drawn from the National Longitudinal Survey of Youth (NLSY). The NLSY is a longitudinal survey of youth who were born between the years 1957 and 1965 . It is an ongoing annual survey, begun in 1979 , designed to collect information from the respondents about a wide variety of subjects. For the purposes of this paper, the NLSY provides information on educational achievement and family background. In addition, all children of female respondents have been administered a variety of cognitive tests. Thus, there is information on the cognitive achievement and family background of a large number of children born between the years 1973 and 1987 . Three samples are constructed from the NLSY data: a child sample, a teenager sample, and a young adult sample.

\section{A. Child Sample}

Explanations of the sibling sex composition effect that center on gender role development and/or classroom instruction are most appropriately tested by examining the relationship between child (or teen) educational outcomes and sibling sex composition. An analysis of children of various ages provides a direct test of the "reference group" hypothesis and will reveal at what age, if any, sibling sex composition begins to affect educational achievement. Indeed, most of the literature cited by Butcher and Case (1994) to document the potential importance of a "reference group" explanation of the sibling sex composition effect are studies of children and teenagers. Thus, analyzing the relationship between sibling sex composition and educational achievement of school age children will provide a more direct test of this hypothesis than that found in Butcher and Case (1994). The use of a sample of children cannot by itself differentiate between the "reference group" or intrafamily resource allocation explanations of the sibling sex composition effect, but a lack of a significant sibling sex composition effect is strong evidence against the "reference group" hypothesis. 
The child (or teen) sample may also provide a test for the intrafamily resource allocation explanation of the sibling sex composition effect. It is self-evident that families make investments in their child's education. For example, families invest in formal schooling by selecting private versus public schools, or by locating in communities with higher educational expenditures, and families make less formal investments of time and money to enhance child cognitive development. In addition, there is substantial evidence that early success in school leads to greater educational achievement or, in human capital terms, the stock of human capital affects the marginal product of human capital investments. ${ }^{14}$ Thus, differences in intrafamily resource allocations due to sibling sex composition should be revealed relatively early in life. This statement will be particularly true if investments in education at earlier ages are less costly than later educational investments since the total cost of achieving a given stock of human capital will be less than if all investments occurred at a later age.

The child sample consists of all children of female respondents in the NLSY who had at least one valid score on one of three cognitive achievement tests, and who were between the ages of 7 and 13 at some time during the period 1986 to 1992 . The cognitive achievement tests were administered every two years between 1986 and 1992, and test eligibility was determined by the child's age at the time of assessment. For each of the four years in which the tests were administered, all children with a valid test score and who came from intact families were selected. A family is considered to be intact if all living children ever born to the mother reside in the household. ${ }^{15}$ Sibling sex composition is constructed from information about the age and sex of all of the

\footnotetext{
${ }^{14}$ See the work of Lazar and Darlington (1982), Barrington and Hendricks (1989), Cairns et al. (1989) and Grissom and Shepard (1989) for evidence of the effect of early educational achievement on later academic success.

is I drop families that included non-biological children because of the possibility that parental concern for adopted children may differ from their concern for biological children. Restricting the sample to intact families was done to avoid measurement error. The question is whether children who do not usually reside with the mother should be treated as part of the sibship. Family resources may or may not be used to support these children. Families in which the child was put up for adoption are not omitted. Empirically, these sample selection criteria are not that important since less than two percent of children did not live with their mothers, and only one percent of families contained adopted or foster children.
} 
mother's children. The final sample consisted of approximately 5000 child-year observations.

The children of the NLSY are not a representative sample of children in the United States. They are an overrepresentation of children born to relatively young and less educated mothers. The problem is most severe among the older children in the NLSY. The younger children in the NLSY are more representative of the United States population (Baker et al. 1993). The non-representative nature of the sample may limit the value of the findings from this analysis. Having noted this, however, it is also important to mention that the empirical analysis explicitly controls for mother's age and education, two of the dimensions that make this sample non-representative. Thus, it is not obvious that the results of this analysis are of limited value. The NLSY contains a relatively large sample of children from diverse backgrounds and in many ways is ideal for the purposes of this study.

The three cognitive achievement tests used in the analysis consist of the math, reading recognition and reading comprehension portions of the Peabody Individual Achievement Test (PIAT). The PIAT is a widely used assessment of cognitive ability and academic achievement, and has been found to be a reliable and valid measure of various aspects of child cognitive development (Baker et al. 1993). The PIAT reading recognition test measures word recognition and pronunciation ability. The PIAT reading comprehension test measures the ability to derive meaning from sentences that are read silently. The PIAT math test measures the child's attainment in mathematics as taught in mainstream education.

The other explanatory variables used in the analysis of child educational achievement include, child attributes - age, race, and birth order; characteristics of the mother - age, education, marital status, and score on the armed forces qualifications test (AFQT); and family background measures - size of sibship, sibling sex composition, family income and welfare recipiency. A more detailed description of these variables are contained in the appendix. 


\section{B. Teenager and Adult Samples}

The teenager and adult samples were drawn from the main NLSY files. In 1993, the NLSY collected retrospective information on the sex and age of all of the respondents' siblings. Using this information, measures of sibling sex composition were constructed for all respondents interviewed in 1993.

The teenager sample consists of all respondents with valid sibling information who were between the ages of 15 and 18 at the time of the 1980 interview. This selection criteria resulted in a sample size of approximately 4100 individuals. The year 1980 was chosen because in that year respondents were given the Armed Forces Qualification Test (AFQT). The AFQT is calculated from the scores on the word knowledge, paragraph comprehension, arithmetic reasoning and numerical operations parts of the Armed Services Vocational Aptitude Battery (ASVAB). I use the AFQT percentile score calculated according to the most recent recommendations (i.e., 1989) of the Department of Defense who developed the test. Since most of the respondents of this age were still in high school, the AFQT is the measure of educational achievement used for this sample.

The adult sample consists of all NLSY respondents with valid information at the time of the 1993 interview. Educational achievement is measured as the number of years of completed education. Respondents were between the ages of 28 and 36 at the time of the 1993 interview, so most will have completed their formal schooling by this time. The sample size was approximately 8400 individuals.

The set of explanatory variables included in the analysis of teenager and adult educational outcomes include respondent characteristics - age, race, and birth order; parental characteristics - family structure when respondent was 14 years old, mother's education, mother figure's labor force participation when respondent was 14 years old, father's education, and father figure's occupation when respondent was 14 years old; and family background measures - sibship size, and religious affiliation. This specification follows closely to that found in Butcher and Case (1994). A more complete description of the variables are contained in the appendix. 


\section{A. Child and Teen Educational Achievement}

Tables 1 and 2 show the estimates of the effect of sibling sex composition on the educational achievement of children between the ages of 7 and 8 and 10 and 11. Educational achievement is measured by the score on a variety of child cognitive tests. All of the regression models were estimated separately by sex and age of the child. Separate estimates by race were not obtained due to the results of preliminary specification tests. The results of a series of F-tests indicated that pooling respondents of all races was valid as long as separate race specific dummy variables were included in the model, and sibling sex composition was interacted with these race dummy variables. ${ }^{16}$ For each cognitive achievement measure, a variety of models were estimated and differ depending on how sibling sex composition is measured. All models are estimated by ordinary least squares procedures and a complete set of results for two representative models can be found in the appendix. ${ }^{17}$

Table 1 contains the estimates for a sample of male children. The left panel of Table 1 lists the results for children between the ages of 7 and 8 and the right panel lists the results for children between the ages of 10 and 11. Each of the measures of sibling sex composition have been interacted with race specific dummy variables and the coefficients associated with these interaction terms are listed in Table 1 . Since the sibling sex composition effect was interacted with all racial dummy variables, the coefficient associated with each interaction gives the total effect of sibling sex composition for that racial group. ${ }^{18}$ The three racial and ethnic

\footnotetext{
${ }^{16}$ The smallest p-value associated with the F-tests for all of the samples in Tables 1 through 4 was .11 , and most of the p-values were over .25 . Three racial/ethnic groups were formed: non-black/nonHispanic, black and Hispanic.

${ }^{17}$ The standard errors reported in Tables 1 through 4 are calculated assuming that the observations are independent. This is not the case since siblings and cousins are included in the same sample, although the two year groupings tends to limit the magnitude of the problem. The reported standard errors are biased, and smaller than the true estimates.

18 In many cases a model like this will be specified with $n-l$ interaction terms where $n$ is the number
} 
groups examined are: black, non-Hispanic; Hispanic; and non-black, non-Hispanic (white).

Although there are a few statistically significant estimates listed in Table 1, the majority of the estimates of the effect of sibling sex composition on cognitive achievement are insignificant. In fact, a large preponderance of the estimates are smaller than their standard errors. If we examine only the signs of the estimates, the presence of sisters, or the greater the number of sisters in a family as measured by the proportion of sisters, tends to have a positive effect on the test scores of white children between the ages of 7 and 11 . Similarly, the presence of brothers tends to decrease the test scores of white children. These results are qualified, however, by the imprecise nature of the estimates. Among black children, the presence of brothers tends to decrease the test scores of children between the ages of 10 and 11 . The estimates associated with the presence of (older) brothers are always negative and are either significant or close to being significant at the .05 level. The only significant estimates associated with Hispanic male children are those related to the presence of older brothers. In this case, older brothers have a positive effect on test scores of Hispanic male children age 10 and 11. Assessing the results in Table 1, it is reasonable to conclude that sibling sex composition is for the most part unrelated to the cognitive achievement of male children between the ages of 7 and 8 and 10 and 11.

The results pertaining to sibling sex composition do not reflect the overall predictive power of the regressions. Estimates associated with other variables in the model are often significant and have the expected sign (see the appendix). For example, mother's AFQT score is always positive and significantly related to cognitive achievement, as is the age of the child. In addition, the number of siblings and family poverty status are always negatively related to cognitive achievement. The adjusted $R$-square measures associated with the

of distinct categories of the characteristic defined by the dummy variables. The coefficient estimates associated with the interaction terms in this specification measure the differential impact of a variable between the reference group and a particular group. I am interested in the total effect, and not the differential effect. 
regressions listed in Table 1 are in the .2 to .3 range.

Table 2 lists the estimates of the effect of sibling sex composition on female children between the ages of 7 and 8 and 10 and 11 , and its presentation is similar to that of Table 1 . The estimates in Tabie 2 suggest a conclusion similar to that of male children the same age, namely that sibling sex composition appears, for the most part, to be unrelated to cognitive achievement. There are two notable exceptions to this statement. Among black, female children age 10 and 11 , the presence of older brothers has a positive effect on tests scores, and among Hispanic, female children age 7 and 8 , the presence of older brothers has a negative effect on test scores.

In Tables 3 and 4 , the estimates of the effect of sibling sex composition on the educational achievement of teenagers are reported. The sample of teenagers between the ages of 12 and 13 are the children of NLSY respondents who were observed at some point during the 1986 to 1992 time period. It is important to note that this sample may not be very representative of a national sample of children of this age because of the relative young age of the mothers in the NLSY survey. To be included in this sample, a child must have been born between the years of 1973 and 1979, a period during which the NLSY respondents were between the ages of 8 and 21 . Thus, this group of children were born to relatively young mothers. The sample of 15 to 18 year old teenagers are NLSY respondents who were this age at the time of the 1980 interview. This sample of teenagers is expected to be representative of all teenagers of that age at that time.

The presentation of Tables 3 and 4 are similar to that of Tables 1 and 2; Table 3 contains the results for the male sample and Table 4 lists the estimates associated with the female sample. The estimates of the effect of sibling sex composition on the cognitive achievement of 12 and 13 year old males are never statistically significant. Thus, for male children of this age sibling sex composition does not appear to be related to cognitive achievement. Among male teenagers between the ages of 15 and 18 , sibling sex composition has a significant effect among black families. Black male teenagers of this age who grow up with relatively more 
sisters have higher scores on the AFQT than black male teenagers with no or fewer sisters. For example, a black male between the ages of 15 and 18 who had a sister in the household is expected to have an AFQT score that is 5.1 percentage points higher than a black male child without any sisters. The 5.1 percentage points represents a 14 percent increase in the mean AFQT score of the black male sample.

The estimates of the effect of sibling sex composition on female teenagers are listed in Table 4. The results indicate that for white female children between the ages of 12 and 13 the presence of sisters in the household increases their cognitive test scores. For example, having a sister in the household increases a female child's score on the reading comprehension test by 3.5 points, or 7.4 percent. Among the 15 to 18 year old females, sibling sex composition appears to only have an effect in black families. Black female teenagers of this age have higher AFQT test scores when there are relatively more sisters in the household.

In summary, the results in Tables 1 through 4 provide little evidence that sibling sex composition is significantly related to the educational achievement of children and teenagers. While there were several significant estimates of the sibling sex composition effect found in Tables 1 through 4 , the sporadic and inconsistent nature of the results tends to support the above stated conclusion. Similar statements apply with regard to racial differences. While there was some indication of significant racial differences in the effect of sibling sex composition, the evidence in this regard was too sparse to make a definitive statement. One exception to the above, however, pertains to black teenagers between the ages of 15 and 18 . The presence of sisters in the household was significantly related to educational achievement. Black teenagers with relatively more sisters had higher AFQT scores than similar individuals with fewer or no sisters.

\section{B. Adult Educational Attainment}

In addition to examining the relationship between sibling sex composition and child educational achievement, another aim of this paper is to replicate the Butcher and Case (1994) study using a more recent birth cohort. The most recent cohort in the Butcher and Case (1994) analysis was born between the years 1941 
and 1961 and had a mean age of 33 years in 1985. The sample of adults I use were born between 1958 and 1965 and had a mean age of 32 in 1993. In this section I replicate the Butcher and Case (1994) analysis of the determinants of educational attainment using this more recent cohort from the NLSY. As did Butcher and Case (1994), I examine four different outcomes: completed years of education, completion of 12 years of school (HS), completion of more than 12 years of school conditional upon completing 12 years (SC), completion of 16 or more years of school conditional on completing more than 12 years of school (BA). The results are listed in Table 5.

The left panel of Table 5 lists the results for males and the right panel the results for females. Similar to what Butcher and Case (1994) find, sibling sex composition is largely unrelated to white male educational attainment, although the presence of older sisters tends to reduce the educational attainment of white males. Among black males, however, sibling sex composition has a significant effect. Black males who grew up with a greater number of sisters, as measured by the proportion of sisters, obtain more education than similar black males without sisters. The estimates indicate that males from families with all sisters have .77 years more education than males from families with no sisters. In addition, black males who grew up with relatively more sisters are more likely to complete high school and more likely to go on to college conditional upon completing high school than similar black males with fewer sisters.

Contrary to Butcher and Case (1994), I find no effect of sibling sex composition on the educational attainment of white women. In fact, the estimates of the effect of sibling sex composition on high school completion suggest that the presence of sisters increases the likelihood of completing high school, although the estimate is significant at only the .12 level. For a similarly aged sample, Butcher and Case (1994) find that the presence of sisters decreases the likelihood that a woman gets a college degree conditional on going to college. For an older cohort, Butcher and Case (1994) find that the presence of sisters reduces the educational attainment of women by .3 years. Butcher and Case (1994) do not separately report the effects of sibling sex 
composition on the educational attainment of the younger cohort of women in their study. Finally, the estimates in Table 5 indicate the presence of sisters increases the educational attainment of black women by .3 years.

\section{Sensitivity Analyses}

In addition to the models reported in the text, I estimated a variety of other models to test specific hypotheses related to the sibling sex composition effect. First, I included an interaction term between measures of sibling sex composition and family resources. The rationale for this specification stems from the fact that sibling sex composition should have a greater effect among relatively poor families, if intrafamily resource allocations are affected by the gender composition of the children. For the child sample and for teens between the ages of 12 and 13 , I measured family resources as total family income in the previous calendar year, and constructed a dummy variable indicating whether family income is above or below $\$ 20,000$ (approximately the median of the sample). For teens between the ages of 15 and 18 and adults, I categorize low and high income families by whether the father or mother had a college degree.

The estimates (not shown) obtained from these regressions do not indicate that sibling sex composition has a more significant effect in low income families. For children (age 7 to 13), Wald tests of the restriction that the sibling sex composition effect was equal for high and low income families rarely rejected the null hypothesis. Even when the equality restriction was rejected, the separate sibling sex composition estimates were not significantly different from zero. For white teens (age 15-18), Wald tests rejected the null hypothesis of equality, but the separate estimates were not significantly different from zero. For black and Hispanic teens, however, Wald tests did not reject the null hypothesis of equality. Finally, among adults, Wald tests rejected the hypothesis of equality among the black male sample and white female sample, but only among the black male sample was the estimate of the sibling sex composition effect significantly different from zero among low income families. These results confirm earlier findings that there is little evidence indicating that sibling sex composition significantly affects educational achievement. 
In order to test the hypothesis, suggested by the work of Thomas (1994), that gender specific parental preferences for children of a particular sex may lead to a sibling sex composition effect, I re-estimated all models using a sample of single parent families. In the child sample (age 7 to 13), single parent families are defined by whether the child's mother was married at the time the achievement tests were administered. For the teen (age 15-18) and adult samples, single parent families are defined as those in which there was only one parent in the household at age $14 .^{19}$ The estimates (not shown) from these models were similar to those found in Tables 1 through 5, namely that in most cases sibling sex composition had little effect on the educational achievement of children, teens and adults.

A final specification check was to include birth spacing in the model to test whether it was a confounding influence on the estimates of the effect of sibling sex composition. In the analysis of child (age 7 to 13) educational achievement, birth spacing was rarely significant and did not change the estimates of the effect of sibling sex composition. Among teens (age 15 and 18) and adults, however, the estimate of the effect of birth spacing was aimost always positive and statistically significant. The addition of this variable, however, had little effect on the estimates of the effect of sibling sex composition.

\section{Discussion}

In this paper, I have extensively examined the relationship between sibling sex composition and educational achievement. The results of the study suggest that for most groups examined in this paper, sibling sex composition had little effect on educational achievement. The two groups for which sibling sex composition did matter was black teenagers between the ages of 15 and 18 and black adults. For these groups, individuals (males and females) who grew up with a sister, or who had relatively more sisters, had higher levels of educational achievement than persons with no or fewer sisters.

\footnotetext{
19 These definitions of a single parent family result in some amount of measurement error. For the adult sample, however, no other information is available about the parents marital status during
} 
The results of this study contrast sharply with those found in Butcher and Case (1994), and raise questions about whether sibling sex composition is in fact a significant determinant of educational achievement. Evidence supporting the existence of a sibling sex composition effect is limited to one demographic group. The narrow and limited nature of the evidence confirming a sibling sex composition effect is not easily reconciled with the more general theoretical considerations that motivated the analysis. For example, the existence of a sibling sex composition effect among black families is not due to lower family incomes since there is no such effect among poor families of other races, nor is the effect more significant among poor black families. Similarly, the sibling sex composition effect is not the result of the higher incidence of female headed households since there was no observed effect for female headed households of other races. Finally, differences in birth spacing due to parental sex preferences is not the cause of the sibling sex composition effect. Controlling for the timing of births had little effect on the estimates of the effect of sibling sex composition on educational achievement. Thus, most explanations of the sibling sex composition effect based on the evidence presented in this paper would be ad-hoc.

It should be noted that an important difference between the Butcher and Case (1994) study and the current analysis is the different birth cohorts that were analyzed. The current sample of young adults were born between the years 1958 and 1965. Butcher and Case (1994) report significant differences in the sibling sex composition between a birth cohort born between 1920 and 1940 and one born between 1941 and 1961 . The older cohort of women were most affected by the presence of sisters. Thus, the current results preserve the pattern of the Butcher and Case (1994) findings since for adults. I find no evidence that the presence of female siblings adversely affect the educational achievement of women. If anything, I find that the presence of sisters makes it more likely that white women will complete high school, and that black women will attain more education.

childhood. 
More importantly, the results of this study's analysis of the educational achievement of school age children strongly suggest that the "reference group" explanation of the sibling sex composition effect offered by Butcher and Case (1994) is not valid. If child gender role development and classroom instruction are the cause of a sibling sex composition effect, it would naturally follow that educational achievement of school age children would be affected. The results of the present analysis refute such an explanation.

In summary, this paper has found very little evidence of a sibling sex composition effect on educational achievement. While the results of this analysis challenge those previously found, further investigation of the issue may be warranted for a variety of reasons. First, the PIAT achievement test and the AFQT, used as proxy variables for child and teen educational achievement, may be relatively noisy measures of educational achievement. Therefore, the effect of sibling sex composition on educational achievement may be obscured by measurement error in the dependent variable. Second, as suggested by McClelland (1983), it may not be feasible to test economic models of family behavior in the presence of significant unobserved heterogeneity related to parental preferences for children of a particular gender. Finally, the results of this study may be sample specific, which may be particularly relevant for the child sample since it is not representative of the population of all children. 


\section{References}

American Association of University Women Educational Foundation, The AAUW Report. How Schools

Shortchange Girls, Wellesley, MA.: Wellesley College Center for Research on Women, 1992.

Baker, Paula C., Canada K. Keck, Frank L. Mott, and Stephen V. Quinlan, NLSY Child Handbook, Columbus, OH.: Center for Human Resource Research, 1993.

Barrington, Byron L., and Bryan Hendricks. "Differentiating Characteristics of High School Graduates, Dropouts, and Nongraduates." Journal of Education Research 82 (1989), pp. 309-319.

Becker, Gary S., A Treatise on the Family, Cambridge, MA.: Harvard University Press, 1991.

Becker, Gary S., and Nigel Tomes, "An Equilibrium Theory of the Distribution of Income and Intergenerational Mobility," Joumal of Political Economy 87 (1979), pp. 1153-1189.

Becker, Gary S., and Nigel Tomes, "Human capital and the Rise and Fall of Families," Journal of Labor Economics 4 (1986) Supplement, pp. S1-S39.

Berhman, Jere R., Intrahousehold Allocation of Nutrients and Gender Effects: A Survey of Structural and Reduced Form Estimates," in Nutrition and Poverty, S. R. Osmani, Ed., Oxford: Oxford University Press, 1992, pp. 287-355.

Berhman, Jere R., Robert A. Pollak, and Paul Taubman, "Parental Preferences and Provision for Progeny," Journal of Political Economy 90 (1982), pp. 52-73.

Berhman, Jere R., Robert A. Pollak, and Paul Taubman, "Do Parents Favor Boys?," International Economic Review 27 (1986), pp. 33-54.

Berhman, Jere R., Mark R. Rosenzweig, and Paul Taubman, "Endowments and the Allocation of Schooling in the Market: The Twins Experiment?," Joumal of Political Economy 102 (1994), pp.1131-1174.

Butcher, Kristin F., and Anne Case, "The Effect of Sibling Sex Composition on Women's Education and Earnings," The Quarterly Journal of Economics 109 (1994), pp. 531-563.

Cairns, Robert B., Beverley D. Cairns, and Holly J. Neckerman. "Early School Dropout: Configurations and Determinants." Child Development 60 (1989), pp. 1437-1452.

Grissom, James B., and Lorrie A. Shepard. "Repeating and Dropping Out of School." In Flunking Grades:

Research and Policies on Retention, Edited by Lorrie A. Shepard and Mary Lee Smith. New York: The Falmer Press. 1989.

Lazar, Irving and Richard Darlington. Lasting Effects of Early Education: A Report from the Consortium for Longitudinal Studies. Chicago: University of Chicago Press. 1982. 
McClelland, Gary H. "Measuring Sex Preferences and Their Effects on Fertility." In Sex Selection of Children, edited by Neil G. Bennett. New York: Academic Press. 1983.

Powell, Brian and Lala Carr Steelman. "The Liability of Brothers: Paying for College and the Sex Composition of the Family." Sociology of Education 62 (1989), pp. 134-147.

Rosenzweig, Mark R. "Birth Spacing and Sibling Inequality: Asymmetric Information Within the Family." International Economic Review 27 (1986), pp. 55-76.

Teachman, Jay, and Paul T. Schollaert. "Gender of Children and Birth Timing." Demography 26 (1989), pp. $411-424$.

Thomas, Duncan. “Like Father, Like Son; Like Mother, Like Daughter: Parental resources and Child Height." Journal of Human Resources 29 (1994), pp. 950-988.

Zajonc, Robert B. "Family Configuration and Intelligence." Science 192 (April 16, 1976), pp. 227-236. 
Table 1

Estimates of the Effect of Sibling Sex Composition

on the Cognitive Achievement of Male Children Between the Ages of 7 and 11

\begin{tabular}{|c|c|c|c|c|c|c|}
\hline \multirow[b]{2}{*}{ Sibling Measure } & \multicolumn{3}{|c|}{ Age $7-8$} & \multicolumn{3}{|c|}{ Age 10-11 } \\
\hline & $\begin{array}{l}\text { PIAT } \\
\text { MATH }\end{array}$ & $\begin{array}{c}\text { PIAT } \\
\text { READ R }\end{array}$ & $\begin{array}{c}\text { PIAT } \\
\text { READ C }\end{array}$ & $\begin{array}{l}\text { PIAT } \\
\text { MATH }\end{array}$ & $\begin{array}{c}\text { PIAT } \\
\text { READ R }\end{array}$ & $\begin{array}{c}\text { PIAT } \\
\text { READ C }\end{array}$ \\
\hline $\begin{array}{l}\text { White } \times \text { Proportion of } \\
\text { Siblings-Sisters }\end{array}$ & $\begin{array}{l}-0.1329 \\
(0.7946)\end{array}$ & $\begin{array}{c}0.5876 \\
(0.8604)\end{array}$ & $\begin{array}{c}0.1701 \\
(0.8949)\end{array}$ & $\begin{array}{c}1.2176 \\
(1.1222)\end{array}$ & $\begin{array}{c}0.9074 \\
(1.5651)\end{array}$ & $\begin{array}{c}0.1500 \\
(1.3984)\end{array}$ \\
\hline $\begin{array}{l}\text { Black x Proportion of } \\
\text { Siblings-Sisters }\end{array}$ & $\begin{array}{l}-0.8996 \\
(1.1503)\end{array}$ & $\begin{array}{c}0.3377 \\
(1.2433)\end{array}$ & $\begin{array}{l}2.3564+ \\
(1.3099)\end{array}$ & $\begin{array}{c}0.1816 \\
(1.6075)\end{array}$ & $\begin{array}{c}0.1715 \\
(2.2192)\end{array}$ & $\begin{array}{c}0.9900 \\
(1.9939)\end{array}$ \\
\hline $\begin{array}{l}\text { Hispanic } \times \text { Proportion of } \\
\text { Siblings-Sisters }\end{array}$ & $\begin{array}{l}-0.3277 \\
(0.9796)\end{array}$ & $\begin{array}{c}-0.4634 \\
(1.0577)\end{array}$ & $\begin{array}{c}-0.1443 \\
(1.0832)\end{array}$ & $\begin{array}{l}-1.8125 \\
(1.2110)\end{array}$ & $\begin{array}{l}-0.2060 \\
(1.6750)\end{array}$ & $\begin{array}{c}0.6307 \\
(1.5010)\end{array}$ \\
\hline $\begin{array}{l}\text { White } x \text { Proportion of Older } \\
\text { Siblings-Sisters }\end{array}$ & $\begin{array}{c}0.0273 \\
(0.8566)\end{array}$ & $\begin{array}{c}1.2853 \\
(0.9243)\end{array}$ & $\begin{array}{c}1.0213 \\
(0.9610)\end{array}$ & $\begin{array}{c}1.2316 \\
(1.1762)\end{array}$ & $\begin{array}{c}0.5584 \\
(1.6348)\end{array}$ & $\begin{array}{c}0.0600 \\
(1.4588)\end{array}$ \\
\hline $\begin{array}{l}\text { Black } \times \text { Proportion of Older } \\
\text { Siblings-Sisters }\end{array}$ & $\begin{array}{l}-1.0383 \\
(1.3720)\end{array}$ & $\begin{array}{l}-1.2966 \\
(1.4820)\end{array}$ & $\begin{array}{c}1.5750 \\
(1.5752)\end{array}$ & $\begin{array}{c}0.0054 \\
(1.7753)\end{array}$ & $\begin{array}{l}-0.5859 \\
(2.4462)\end{array}$ & $\begin{array}{c}1.1019 \\
(2.1901)\end{array}$ \\
\hline $\begin{array}{l}\text { Hispanic } \mathrm{x} \text { proportion of } \\
\text { Older Siblings-Sisters }\end{array}$ & $\begin{array}{l}-0.6140 \\
(1.0774)\end{array}$ & $\begin{array}{c}-0.1932 \\
(1.1640)\end{array}$ & $\begin{array}{c}-0.0912 \\
(1.1956)\end{array}$ & $\begin{array}{c}-0.1262 \\
(1.2650)\end{array}$ & $\begin{array}{c}0.3619 \\
(1.7466)\end{array}$ & $\begin{array}{c}1.2411 \\
(1.5666)\end{array}$ \\
\hline White $x$ Any Sisters & $\begin{array}{l}-0.1850 \\
(0.7181)\end{array}$ & $\begin{array}{c}0.5545 \\
(0.7793)\end{array}$ & $\begin{array}{c}0.2188 \\
(0.8131)\end{array}$ & $\begin{array}{c}0.8125 \\
(1.0111)\end{array}$ & $\begin{array}{c}1.4131 \\
(1.4054)\end{array}$ & $\begin{array}{c}0.2506 \\
(1.2556)\end{array}$ \\
\hline Black x Any Sisters & $\begin{array}{l}-1.0596 \\
(0.9838)\end{array}$ & $\begin{array}{c}-0.7053 \\
(1.0636)\end{array}$ & $\begin{array}{c}0.7315 \\
(1.1197)\end{array}$ & $\begin{array}{c}-1.1077 \\
(1.3214)\end{array}$ & $\begin{array}{l}-1.7665 \\
(1.8225)\end{array}$ & $\begin{array}{c}-0.4596 \\
(1.6349)\end{array}$ \\
\hline Hispanic x Any Sisters & $\begin{array}{l}-0.7525 \\
(0.8775)\end{array}$ & $\begin{array}{c}-0.2920 \\
(0.9501)\end{array}$ & $\begin{array}{c}0.3963 \\
(0.9778)\end{array}$ & $\begin{array}{l}-1.1559 \\
(1.1189)\end{array}$ & $\begin{array}{c}0.7481 \\
(1.5497)\end{array}$ & $\begin{array}{c}0.9532 \\
(1.3878)\end{array}$ \\
\hline White $\times$ Any Older Sisters & $\begin{array}{l}-0.0256 \\
(0.7198)\end{array}$ & $\begin{array}{c}1.5336^{*} \\
(0.7772)\end{array}$ & $\begin{array}{c}1.2392^{*} \\
(0.8086)\end{array}$ & $\begin{array}{c}0.5568 \\
(1.0040)\end{array}$ & $\begin{array}{c}0.7188 \\
(1.3927)\end{array}$ & $\begin{array}{l}-0.0973 \\
(1.2461)\end{array}$ \\
\hline Black x Any Older Sisters & $\begin{array}{l}-1.0835 \\
(0.9859)\end{array}$ & $\begin{array}{l}-1.5312 \\
(1.0689)\end{array}$ & $\begin{array}{c}0.3778 \\
(1.1376)\end{array}$ & $\begin{array}{c}-0.6992 \\
(1.2964)\end{array}$ & $\begin{array}{l}-1.8576 \\
(1.7846)\end{array}$ & $\begin{array}{c}0.0398 \\
(1.6027)\end{array}$ \\
\hline Hispanic x Any Older Sisters & $\begin{array}{c}-0.5318 \\
(0.8391)\end{array}$ & $\begin{array}{c}0.1933 \\
(0.9049)\end{array}$ & $\begin{array}{c}0.3166 \\
(0.9361)\end{array}$ & $\begin{array}{c}-0.1798 \\
(1.0135)\end{array}$ & $\begin{array}{c}0.7393 \\
(1.3989)\end{array}$ & $\begin{array}{c}2.1293+ \\
(1.2556)\end{array}$ \\
\hline White $x$ Any Brothers & $\begin{array}{c}-0.0585 \\
(0.7318)\end{array}$ & $\begin{array}{c}-0.5589 \\
(0.7891)\end{array}$ & $\begin{array}{c}-0.0572 \\
(0.8183)\end{array}$ & $\begin{array}{c}-0.5109 \\
(1.0463)\end{array}$ & $\begin{array}{c}-0.0207 \\
(1.4534)\end{array}$ & $\begin{array}{c}0.1787 \\
(1.2962)\end{array}$ \\
\hline Black x Any Brothers & $\begin{array}{c}0.5103 \\
(1.0864)\end{array}$ & $\begin{array}{c}-1.7736 \\
(1.1755)\end{array}$ & $\begin{array}{c}-2.9795^{*} \\
(1.2464)\end{array}$ & $\begin{array}{c}-1.8607 \\
(1.5327)\end{array}$ & $\begin{array}{c}-3.5707+ \\
(2.1078)\end{array}$ & $\begin{array}{c}-3.2713+ \\
(1.8976)\end{array}$ \\
\hline Hispanic x Any Brothers & $\begin{array}{c}-0.6610 \\
(0.8828)\end{array}$ & $\begin{array}{c}0.5343 \\
(0.9523)\end{array}$ & $\begin{array}{c}0.5530 \\
(0.9816)\end{array}$ & $\begin{array}{c}0.8856 \\
(1.0687)\end{array}$ & $\begin{array}{c}-0.0427 \\
(1.4712)\end{array}$ & $\begin{array}{c}-0.2129 \\
(1.3179)\end{array}$ \\
\hline White $x$ Any Older Brothers & $\begin{array}{c}-0.3090 \\
(0.7213)\end{array}$ & $\begin{array}{c}-0.3107 \\
(0.7286)\end{array}$ & $\begin{array}{c}-0.5964 \\
(0.7616)\end{array}$ & $\begin{array}{c}-1.1622 \\
(1.0412)\end{array}$ & $\begin{array}{c}-1.1139 \\
(1.0514)\end{array}$ & $\begin{array}{c}-0.9039 \\
(1.0501)\end{array}$ \\
\hline Black x Any Older Brothers & $\begin{array}{c}-0.4848 \\
(0.9839)\end{array}$ & $\begin{array}{c}-0.4574 \\
(0.9975)\end{array}$ & $\begin{array}{c}-0.2435 \\
(1.0564)\end{array}$ & $\begin{array}{c}-1.6786 \\
(1.3770)\end{array}$ & $\begin{array}{c}-1.7332 \\
(1.3809)\end{array}$ & $\begin{array}{c}-1.7108 \\
(1.3815)\end{array}$ \\
\hline Hispanic x Any Older Brothers & $\begin{array}{c}0.2182 \\
(0.8403)\end{array}$ & $\begin{array}{c}0.2355 \\
(0.8507)\end{array}$ & $\begin{array}{c}0.1282 \\
(0.8835)\end{array}$ & $\begin{array}{c}1.7669+ \\
(1.0038)\end{array}$ & $\begin{array}{c}1.8855+ \\
(1.0074)\end{array}$ & $\begin{array}{l}2.0186^{*} \\
(1.0108)\end{array}$ \\
\hline Observations & 1303 & 1284 & 1182 & 856 & 846 & 833 \\
\hline
\end{tabular}

Notes: Six separate models are estimated for each dependent variable. Models differ according to which measure of sibling sex composition is used in the analysis. PIAT MATH represents the raw score on the math portion of the Peabody Individual Achievement Test. PIAT READ R represents the raw score on the reading recognition part of the Peabody Individual Achievement Test. PIAT READ C represents the raw score on the reading comprehension part of the Peabody Individual Achievement Test. All models include controls for the following: child's age, child's race, child's birth order, the number of children in family, mother's education, mother's age, mother's marital status, mother's score on AFQT, receipt of public assistance, and year of test. The appendix contains the complete results from a representative model. Standard errors are in parentheses. $+p<.10, * p<.05, * p<.01$. 
Table 2

Estimates of the Effect of Sibling Sex Composition on the Cognitive Achievement of Female Children Between the Ages of 7 and 11

\begin{tabular}{|c|c|c|c|c|c|c|}
\hline \multirow[b]{2}{*}{ Sibling Measure } & \multicolumn{3}{|c|}{ Age 7-8 } & \multicolumn{3}{|c|}{ Age 10-11 } \\
\hline & $\begin{array}{l}\text { PIAT } \\
\text { MATH }\end{array}$ & $\begin{array}{l}\text { PIAT } \\
\text { READ R }\end{array}$ & $\begin{array}{l}\text { PIAT } \\
\text { READ C }\end{array}$ & $\begin{array}{l}\text { PIAT } \\
\text { MATH }\end{array}$ & $\begin{array}{l}\text { PIAT } \\
\text { READ R }\end{array}$ & $\begin{array}{c}\text { PIAT } \\
\text { READ C }\end{array}$ \\
\hline $\begin{array}{l}\text { White } x \text { Proportion of Siblings- } \\
\text { Sisters }\end{array}$ & $\begin{array}{c}0.0180 \\
(0.8123)\end{array}$ & $\begin{array}{c}0.4000 \\
(0.8452)\end{array}$ & $\begin{array}{c}0.3579 \\
(0.8183)\end{array}$ & $\begin{array}{c}0.4387 \\
(1.0385)\end{array}$ & $\begin{array}{l}0.1655 \\
(1.4049)\end{array}$ & $\begin{array}{c}1.0857 \\
(1.2776)\end{array}$ \\
\hline $\begin{array}{l}\text { Black x Proportion of Siblings- } \\
\text { Sisters }\end{array}$ & $\begin{array}{l}-0.0810 \\
(1.3033)\end{array}$ & $\begin{array}{c}0.4115 \\
(1.3581)\end{array}$ & $\begin{array}{l}-0.4554 \\
(1.3312)\end{array}$ & $\begin{array}{c}1.3809 \\
(1.4983)\end{array}$ & $\begin{array}{c}0.1294 \\
(2.0432)\end{array}$ & $\begin{array}{c}1.9624 \\
(1.8476)\end{array}$ \\
\hline $\begin{array}{l}\text { Hispanic x Proportion of } \\
\text { Siblings-Sisters }\end{array}$ & $\begin{array}{c}1.4373 \\
(0.9336)\end{array}$ & $\begin{array}{r}-0.1188 \\
(0.9715)\end{array}$ & $\begin{array}{l}-0.1092 \\
(0.9461)\end{array}$ & $\begin{array}{l}-1.5181 \\
(0.9908)\end{array}$ & $\begin{array}{c}0.2234 \\
(1.3437)\end{array}$ & $\begin{array}{c}0.6248 \\
(1.2252)\end{array}$ \\
\hline $\begin{array}{l}\text { White } x \text { Proportion of Older } \\
\text { Siblings-Sisters }\end{array}$ & $\begin{array}{c}0.8398 \\
(0.9056)\end{array}$ & $\begin{array}{c}0.7453 \\
(0.9399)\end{array}$ & $\begin{array}{c}1.4196 \\
(0.9118)\end{array}$ & $\begin{array}{l}-0.0808 \\
(1.1175)\end{array}$ & $\begin{array}{c}0.7470 \\
(1.5159)\end{array}$ & $\begin{array}{c}0.7443 \\
(1.3751)\end{array}$ \\
\hline $\begin{array}{l}\text { Black x Proportion of Older } \\
\text { Siblings-Sisters }\end{array}$ & $\begin{array}{l}-0.2488 \\
(1.4945)\end{array}$ & $\begin{array}{r}-1.0448 \\
(1.5506)\end{array}$ & $\begin{array}{l}-1.0072 \\
(1.5343)\end{array}$ & $\begin{array}{c}1.9147 \\
(1.5905)\end{array}$ & $\begin{array}{c}-0.2923 \\
(2.1770)\end{array}$ & $\begin{array}{c}1.2350 \\
(1.9566)\end{array}$ \\
\hline $\begin{array}{l}\text { Hispanic } x \text { proportion of Older } \\
\text { Siblings-Sisters }\end{array}$ & $\begin{array}{c}0.4531 \\
(1.0210)\end{array}$ & $\begin{array}{c}-1.0390 \\
(1.0614)\end{array}$ & $\begin{array}{c}-0.7795 \\
(1.0266)\end{array}$ & $\begin{array}{c}-1.4104 \\
(1.0342)\end{array}$ & $\begin{array}{c}2.9999 \\
(1.4034)\end{array}$ & $\begin{array}{c}0.5961 \\
(1.2834)\end{array}$ \\
\hline White $x$ Any Sisters & $\begin{array}{c}0.5611 \\
(0.7375)\end{array}$ & $\begin{array}{c}0.4269 \\
(0.7687)\end{array}$ & $\begin{array}{c}0.2629 \\
(0.7437)\end{array}$ & $\begin{array}{c}1.2341 \\
(0.9133)\end{array}$ & $\begin{array}{c}0.5084 \\
(1.2395)\end{array}$ & $\begin{array}{c}1.4804 \\
(1.1326)\end{array}$ \\
\hline Black $x$ Any Sisters & $\begin{array}{c}1.3306 \\
(1.0939)\end{array}$ & $\begin{array}{c}0.6129 \\
(1.1426)\end{array}$ & $\begin{array}{c}0.0899 \\
(1.1131)\end{array}$ & $\begin{array}{c}2.5740^{*} \\
(1.2545)\end{array}$ & $\begin{array}{c}1.4568 \\
(1.7103)\end{array}$ & $\begin{array}{c}2.4407 \\
(1.5614)\end{array}$ \\
\hline Hispanic $x$ Any Sisters & $\begin{array}{c}1.0830 \\
(0.8631)\end{array}$ & $\begin{array}{c}0.3295 \\
(0.8994)\end{array}$ & $\begin{array}{c}0.6029 \\
(0.8761)\end{array}$ & $\begin{array}{c}-1.7223+ \\
(0.9280)\end{array}$ & $\begin{array}{c}0.2848 \\
(1.2627)\end{array}$ & $\begin{array}{c}0.6977 \\
(1.1483)\end{array}$ \\
\hline White $x$ Any Older Sisters & $\begin{array}{c}0.4023 \\
(0.7597)\end{array}$ & $\begin{array}{c}0.6393 \\
(0.7897)\end{array}$ & $\begin{array}{c}0.4909 \\
(0.7663)\end{array}$ & $\begin{array}{c}0.5495 \\
(0.9197)\end{array}$ & $\begin{array}{c}0.8548 \\
(1.2482)\end{array}$ & $\begin{array}{c}0.8529 \\
(1.1397)\end{array}$ \\
\hline Black $x$ Any Older Sisters & $\begin{array}{c}0.6848 \\
(1.0810)\end{array}$ & $\begin{array}{c}0.0294 \\
(1.1271)\end{array}$ & $\begin{array}{c}-0.6237 \\
(1.1073)\end{array}$ & $\begin{array}{c}2.0503+ \\
(1.2064)\end{array}$ & $\begin{array}{c}1.1829 \\
(1.6417)\end{array}$ & $\begin{array}{c}2.2795 \\
(1.4950)\end{array}$ \\
\hline Hispanic x Any Older Sisters & $\begin{array}{c}0.0462 \\
(0.8107)\end{array}$ & $\begin{array}{c}-0.2354 \\
(0.8419)\end{array}$ & $\begin{array}{c}-0.2335 \\
(0.8183)\end{array}$ & $\begin{array}{r}-1.6403+ \\
(0.8831)\end{array}$ & $\begin{array}{c}-0.1138 \\
(1.1998)\end{array}$ & $\begin{array}{c}0.6221 \\
(1.0921)\end{array}$ \\
\hline White $x$ Any Brothers & $\begin{array}{c}0.0995 \\
(0.7585)\end{array}$ & $\begin{array}{c}-0.5822 \\
(0.7892)\end{array}$ & $\begin{array}{l}-0.6651 \\
(0.7648)\end{array}$ & $\begin{array}{c}0.1680 \\
(0.9957)\end{array}$ & $\begin{array}{c}0.5015 \\
(1.3490)\end{array}$ & $\begin{array}{c}-0.3677 \\
(1.2232)\end{array}$ \\
\hline Black x Any Brothers & $\begin{array}{c}1.4091 \\
(1.2282)\end{array}$ & $\begin{array}{c}0.8816 \\
(1.2774)\end{array}$ & $\begin{array}{c}1.2213 \\
(1.2630)\end{array}$ & $\begin{array}{c}1.1287 \\
(1.3915)\end{array}$ & $\begin{array}{c}1.3202 \\
(1.8991)\end{array}$ & $\begin{array}{c}-0.5366 \\
(1.7082)\end{array}$ \\
\hline Hispanic $\times$ Any Brothers & $\begin{array}{c}-1.6369+ \\
(0.8473)\end{array}$ & $\begin{array}{c}0.2937 \\
(0.8815)\end{array}$ & $\begin{array}{c}0.7493 \\
(0.8602)\end{array}$ & $\begin{array}{c}0.4671 \\
(0.9107)\end{array}$ & $\begin{array}{c}-0.7113 \\
(1.2309)\end{array}$ & $\begin{array}{c}-0.7596 \\
(1.1267)\end{array}$ \\
\hline White $x$ Any Older Brothers & $\begin{array}{c}-0.0699 \\
(0.7377)\end{array}$ & $\begin{array}{c}-0.0975 \\
(0.7353)\end{array}$ & $\begin{array}{c}-0.1576 \\
(0.7511)\end{array}$ & $\begin{array}{c}0.4019 \\
(0.9380)\end{array}$ & $\begin{array}{c}0.3996 \\
(0.9512)\end{array}$ & $\begin{array}{c}0.2552 \\
(0.9452)\end{array}$ \\
\hline Black $x$ Any Older Brothers & $\begin{array}{c}1.1861 \\
(1.0936)\end{array}$ & $\begin{array}{c}0.9461 \\
(1.0931)\end{array}$ & $\begin{array}{c}0.9568 \\
(1.1368)\end{array}$ & $\begin{array}{l}2.4461+ \\
(1.2704)\end{array}$ & $\begin{array}{c}2.4441+ \\
(1.2950)\end{array}$ & $\begin{array}{l}2.2460+ \\
(1.2799)\end{array}$ \\
\hline Hispanic $x$ Any Older Brothers & $\begin{array}{c}-2.1140^{* *} \\
(0.8100)\end{array}$ & $\begin{array}{c}-2.0972^{*} \\
(0.8065)\end{array}$ & $\begin{array}{l}-2.1151 " \\
(0.8321)\end{array}$ & $\begin{array}{c}0.3720 \\
(0.8872)\end{array}$ & $\begin{array}{c}0.4595 \\
(0.8988)\end{array}$ & $\begin{array}{c}0.3450 \\
(0.8963)\end{array}$ \\
\hline Observations & 1293 & 1280 & 1225 & 841 & 825 & 825 \\
\hline
\end{tabular}

Notes: Six separate models are estimated for each dependent variable. Models differ according to which measure of sibling sex composition is used in the analysis. PIAT MATH represents the raw score on the math portion of the Peabody Individual Achievement Test. PIAT READ R represents the raw score on the reading recognition part of the Peabody Individual Achievement Test. PIAT READ C represents the raw score on the reading comprehension part of the Peabody Individual Achievement Test. All models include controls for the following: child's age, child's race, child's birth order, the number of children in family, mother's education, mother's age, mother's marital status, mother's score on AFQT, receipt of public assistance, and year of test. The appendix contains the complete results from a representative model. Standard errors are in parentheses. $+p<.10$, * $p<.05, * * p<.01$. 
Table 3

Estimates of the Effect of Sibling Sex Composition on the Cognitive Achievement of Male Teenagers Between the Ages of 12 and 18

\begin{tabular}{|c|c|c|c|c|}
\hline Sibling Measures & $\begin{array}{l}\text { PIAT } \\
\text { MATH }\end{array}$ & $\begin{array}{c}\text { Age } 12-13 \\
\text { PIAT } \\
\text { READ R }\end{array}$ & $\begin{array}{c}\text { PIAT } \\
\text { READ C }\end{array}$ & $\begin{array}{c}\text { Age } 15-18 \\
\text { AFQT }\end{array}$ \\
\hline $\begin{array}{l}\text { White } x \text { Proportion of } \\
\text { Siblings-Sisters }\end{array}$ & $\begin{array}{c}0.8405 \\
(1.6803)\end{array}$ & $\begin{array}{l}-0.1720 \\
(2.2639)\end{array}$ & $\begin{array}{c}0.3424 \\
(1.9640)\end{array}$ & $\begin{array}{c}1.2432 \\
(3.1452)\end{array}$ \\
\hline $\begin{array}{l}\text { Black x Proportion of } \\
\text { Siblings-Sisters }\end{array}$ & $\begin{array}{c}1.8800 \\
(2.5949)\end{array}$ & $\begin{array}{c}4.1627 \\
(3.4711)\end{array}$ & $\begin{array}{c}2.0413 \\
(3.0383)\end{array}$ & $\begin{array}{l}7.9701+ \\
(4.1176)\end{array}$ \\
\hline $\begin{array}{l}\text { Hispanic x Proportion of } \\
\text { Siblings-Sisters }\end{array}$ & $\begin{array}{c}2.6331 \\
(1.6225)\end{array}$ & $\begin{array}{c}2.4184 \\
(2.1882)\end{array}$ & $\begin{array}{c}1.4395 \\
(1.9379)\end{array}$ & $\begin{array}{l}-2.1167 \\
(5.5326)\end{array}$ \\
\hline $\begin{array}{l}\text { White } \times \text { Proportion of } \\
\text { Older Siblings-Sisters }\end{array}$ & $\begin{array}{c}1.7491 \\
(1.7172)\end{array}$ & $\begin{array}{c}2.7951 \\
(2.3087)\end{array}$ & $\begin{array}{c}1.3249 \\
(2.0116)\end{array}$ & $\begin{array}{c}0.1026 \\
(1.9588)\end{array}$ \\
\hline $\begin{array}{l}\text { Black x Proportion of } \\
\text { Older Siblings-Sisters }\end{array}$ & $\begin{array}{c}3.0741 \\
(2.7474)\end{array}$ & $\begin{array}{c}4.5082 \\
(3.6669)\end{array}$ & $\begin{array}{c}3.5464 \\
(3.2049)\end{array}$ & $\begin{array}{c}0.9490 \\
(2.4866)\end{array}$ \\
\hline $\begin{array}{l}\text { Hispanic x Proportion of } \\
\text { Older Siblings-Sisters }\end{array}$ & $\begin{array}{c}2.4414 \\
(1.6406)\end{array}$ & $\begin{array}{c}2.4823 \\
(2.2112)\end{array}$ & $\begin{array}{c}1.4646 \\
(1.9551)\end{array}$ & $\begin{array}{c}1.3894 \\
(3.0983)\end{array}$ \\
\hline White $x$ Any Sisters & $\begin{array}{c}0.2155 \\
(1.5871)\end{array}$ & $\begin{array}{c}-0.1327 \\
(2.1423)\end{array}$ & $\begin{array}{c}0.4749 \\
(1.8532)\end{array}$ & $\begin{array}{l}-0.5245 \\
(1.8355)\end{array}$ \\
\hline Black $x$ Any Sisters & $\begin{array}{c}1.0889 \\
(2.0313)\end{array}$ & $\begin{array}{c}2.4986 \\
(2.7233)\end{array}$ & $\begin{array}{c}1.4861 \\
(2.3884)\end{array}$ & $\begin{array}{l}5.1196+ \\
(2.7864)\end{array}$ \\
\hline Hispanic $x$ Any Sisters & $\begin{array}{c}2.0824 \\
(1.4886)\end{array}$ & $\begin{array}{c}2.9816 \\
(2.0073)\end{array}$ & $\begin{array}{c}1.7353 \\
(1.7628)\end{array}$ & $\begin{array}{l}-3.4691 \\
(3.4879)\end{array}$ \\
\hline White $x$ Any Older Sisters & $\begin{array}{c}0.7511 \\
(1.5341)\end{array}$ & $\begin{array}{c}1.1983 \\
(2.0637)\end{array}$ & $\begin{array}{c}0.5731 \\
(1.7922)\end{array}$ & $\begin{array}{c}-0.5323 \\
(1.6462)\end{array}$ \\
\hline Black x Any Older Sisters & $\begin{array}{c}1.1943 \\
(2.0041)\end{array}$ & $\begin{array}{c}0.6209 \\
(2.6829)\end{array}$ & $\begin{array}{c}0.8171 \\
(2.3440)\end{array}$ & $\begin{array}{c}1.2646 \\
(2.0296)\end{array}$ \\
\hline Hispanic $x$ Any Older Sisters & $\begin{array}{c}1.4917 \\
(1.4059)\end{array}$ & $\begin{array}{c}2.7448 \\
(1.8942)\end{array}$ & $\begin{array}{c}2.3894 \\
(1.6564)\end{array}$ & $\begin{array}{c}-0.5242 \\
(2.4275)\end{array}$ \\
\hline White $\mathrm{x}$ Any Brothers & $\begin{array}{c}-0.7592 \\
(1.5820)\end{array}$ & $\begin{array}{c}0.9943 \\
(2.1258)\end{array}$ & $\begin{array}{c}1.2324 \\
(1.8478)\end{array}$ & $\begin{array}{c}-1.0933 \\
(1.8311)\end{array}$ \\
\hline Black x Any Brothers & $\begin{array}{c}-2.1461 \\
(2.4744)\end{array}$ & $\begin{array}{c}-3.0755 \\
(3.3062)\end{array}$ & $\begin{array}{c}-0.8976 \\
(2.8790)\end{array}$ & $\begin{array}{c}1.4880 \\
(2.7280)\end{array}$ \\
\hline Hispanic x Any Brothers & $\begin{array}{c}-2.0348 \\
(1.4459)\end{array}$ & $\begin{array}{c}-0.6850 \\
(1.9362)\end{array}$ & $\begin{array}{c}-0.9365 \\
(1.7114)\end{array}$ & $\begin{array}{c}-4.1512 \\
(3.6462)\end{array}$ \\
\hline White $x$ Any Older Brothers & $\begin{array}{c}-1.4662 \\
(1.5740)\end{array}$ & $\begin{array}{c}-1.5376 \\
(1.5751)\end{array}$ & $\begin{array}{c}-1.2291 \\
(1.5758)\end{array}$ & $\begin{array}{c}-0.3015 \\
(1.6761)\end{array}$ \\
\hline Black x Any Older Brothers & $\begin{array}{c}-1.5500 \\
(2.0795)\end{array}$ & $\begin{array}{c}-1.4294 \\
(2.0884)\end{array}$ & $\begin{array}{c}-1.3124 \\
(2.0962)\end{array}$ & $\begin{array}{c}2.1828 \\
(2.0278)\end{array}$ \\
\hline Hispanic $x$ Any Older Brothers & $\begin{array}{c}-1.2757 \\
(1.3929)\end{array}$ & $\begin{array}{c}-1.2001 \\
(1.3999)\end{array}$ & $\begin{array}{c}-1.0148 \\
(1.4071)\end{array}$ & $\begin{array}{c}-4.9299 \\
(2.5070)^{*}\end{array}$ \\
\hline Observations & 528 & 519 & 513 & 2075 \\
\hline
\end{tabular}

Notes: For teenagers 12-13 years of age, see notes from Table 1. For teenagers 15-18 years of age, the percentile score on the Armed Forces Qualifications Test (AFQT) is used as the dependent variable. All models include controls for the following: child's age, child's race, child's birth order,, the number of children in the family, mother's education, mother's labor force status at age 14, father's education, marital status of parents when child was 14, father's occupation at age 14, and religious affiliation. Standard errors are in parentheses. $+p<.10, * p<.05, * * p<.01$. 
Table 4

Estimates of the Effect of Sibling Sex Composition on the Cognitive Achievement of Female Teenagers Between the Ages of 12 and 18

\begin{tabular}{|c|c|c|c|c|}
\hline Sibling Measures & $\begin{array}{c}\text { PIAT } \\
\text { MATH }\end{array}$ & $\begin{array}{c}\text { Age 12-13 } \\
\text { PIAT } \\
\text { READ R }\end{array}$ & $\begin{array}{c}\text { PIAT } \\
\text { READ C }\end{array}$ & $\begin{array}{c}\text { Age 15-18 } \\
\text { AFQT }\end{array}$ \\
\hline $\begin{array}{l}\text { White } \mathrm{x} \text { Proportion of } \\
\text { Siblings-Sisters }\end{array}$ & $\begin{array}{c}2.3196 \\
(1.6214)\end{array}$ & $\begin{array}{c}3.4272 \\
(2.2191)\end{array}$ & $\begin{array}{l}5.0069^{*} \\
(2.0592)\end{array}$ & $\begin{array}{c}4.1426 \\
(2.8763)\end{array}$ \\
\hline $\begin{array}{l}\text { Black } \times \text { Proportion of } \\
\text { Siblings-Sisters }\end{array}$ & $\begin{array}{l}4.2404^{*} \\
(2.1030)\end{array}$ & $\begin{array}{c}3.7005 \\
(2.8746)\end{array}$ & $\begin{array}{c}2.7661 \\
(2.6974)\end{array}$ & $\begin{array}{c}2.5463 \\
(4.0134)\end{array}$ \\
\hline $\begin{array}{l}\text { Hispanic } x \text { Proportion of } \\
\text { Siblings-Sisters }\end{array}$ & $\begin{array}{c}1.0570 \\
(1.3545)\end{array}$ & $\begin{array}{l}-1.1582 \\
(1.8620)\end{array}$ & $\begin{array}{c}0.1027 \\
(1.7144)\end{array}$ & $\begin{array}{c}0.4527 \\
(4.8503)\end{array}$ \\
\hline $\begin{array}{l}\text { White } \mathrm{x} \text { Proportion of } \\
\text { Older Siblings-Sisters }\end{array}$ & $\begin{array}{l}3.9527^{*} \\
(1.7235)\end{array}$ & $\begin{array}{c}3.0977 \\
(2.3642)\end{array}$ & $\begin{array}{l}4.9777^{*} \\
(2.1953)\end{array}$ & $\begin{array}{c}0.6403 \\
(1.7565)\end{array}$ \\
\hline $\begin{array}{l}\text { Black x Proportion of } \\
\text { Older Siblings-Sisters }\end{array}$ & $\begin{array}{c}2.8879 \\
(2.1397)\end{array}$ & $\begin{array}{c}1.9553 \\
(2.9328)\end{array}$ & $\begin{array}{c}0.5114 \\
(2.7539)\end{array}$ & $\begin{array}{c}2.7580 \\
(2.3266)\end{array}$ \\
\hline $\begin{array}{l}\text { Hispanic x Proportion of } \\
\text { Older Siblings-Sisters }\end{array}$ & $\begin{array}{c}0.7808 \\
(1.4179)\end{array}$ & $\begin{array}{l}-0.6879 \\
(1.9518)\end{array}$ & $\begin{array}{c}0.9506 \\
(1.8059)\end{array}$ & $\begin{array}{c}0.9100 \\
(2.8183)\end{array}$ \\
\hline White $x$ Any Sisters & $\begin{array}{c}2.0774 \\
(1.3694)\end{array}$ & $\begin{array}{c}2.0976 \\
(1.8799)\end{array}$ & $\begin{array}{l}3.5396^{*} \\
(1.7450)\end{array}$ & $\begin{array}{c}0.4621 \\
(1.6812)\end{array}$ \\
\hline Black x Any Sisters & $\begin{array}{c}3.3598+ \\
(1.9101)\end{array}$ & $\begin{array}{c}1.3453 \\
(2.6133)\end{array}$ & $\begin{array}{c}-0.9842 \\
(2.4491)\end{array}$ & $\begin{array}{c}3.8482 \\
(2.6341)\end{array}$ \\
\hline Hispanic $x$ Any Sisters & $\begin{array}{c}0.9622 \\
(1.2590)\end{array}$ & $\begin{array}{c}-1.3382 \\
(1.7338)\end{array}$ & $\begin{array}{c}0.1261 \\
(1.5988)\end{array}$ & $\begin{array}{c}-0.2929 \\
(3.0272)\end{array}$ \\
\hline White $x$ Any Older Sisters & $\begin{array}{c}3.2386^{*} \\
(1.3814)\end{array}$ & $\begin{array}{c}2.2252 \\
(1.8981)\end{array}$ & $\begin{array}{c}4.0106^{*} \\
(1.7599)\end{array}$ & $\begin{array}{c}0.7099 \\
(1.5089)\end{array}$ \\
\hline Black x Any Older Sisters & $\begin{array}{c}1.6271 \\
(1.7778)\end{array}$ & $\begin{array}{c}1.3905 \\
(2.4347)\end{array}$ & $\begin{array}{l}-1.1781 \\
(2.2740)\end{array}$ & $\begin{array}{l}3.9808^{*} \\
(1.9343)\end{array}$ \\
\hline Hispanic $x$ Any Older Sisters & $\begin{array}{c}0.7055 \\
(1.2127)\end{array}$ & $\begin{array}{c}-0.6081 \\
(1.6673)\end{array}$ & $\begin{array}{c}1.7065 \\
(1.5430)\end{array}$ & $\begin{array}{c}0.6903 \\
(2.2015)\end{array}$ \\
\hline White $x$ Any Brothers & $\begin{array}{c}-2.2717 \\
(1.5748)\end{array}$ & $\begin{array}{c}-3.0183 \\
(2.1506)\end{array}$ & $\begin{array}{c}-4.2350^{*} \\
(1.9901)\end{array}$ & $\begin{array}{c}-0.4413 \\
(1.7366)\end{array}$ \\
\hline Black x Any Brothers & $\begin{array}{c}-2.5368 \\
(1.8439)\end{array}$ & $\begin{array}{c}-4.2359+ \\
(2.5155)\end{array}$ & $\begin{array}{c}-4.8125^{*} \\
(2.3636)\end{array}$ & $\begin{array}{c}-0.4703 \\
(2.7077)\end{array}$ \\
\hline Hispanic $x$ Any Brothers & $\begin{array}{c}-1.4065 \\
(1.2454)\end{array}$ & $\begin{array}{c}-0.1748 \\
(1.7068)\end{array}$ & $\begin{array}{c}-1.0819 \\
(1.5807)\end{array}$ & $\begin{array}{c}-0.4183 \\
(3.3160)\end{array}$ \\
\hline White $\mathrm{x}$ Any Older Brothers & $\begin{array}{c}-1.5408 \\
(1.4402)\end{array}$ & $\begin{array}{c}-1.6872 \\
(1.4318)\end{array}$ & $\begin{array}{c}-1.6112 \\
(1.4549)\end{array}$ & $\begin{array}{c}0.5644 \\
(1.5079)\end{array}$ \\
\hline Black x Any Older Brothers & $\begin{array}{c}-1.7246 \\
(1.8204)\end{array}$ & $\begin{array}{c}-1.7907 \\
(1.8068)\end{array}$ & $\begin{array}{c}-1.9172 \\
(1.8577)\end{array}$ & $\begin{array}{c}2.3366 \\
(1.9198)\end{array}$ \\
\hline Hispanic $\times$ Any Older Brothers & $\begin{array}{l}-1.3756 \\
(1.2231)\end{array}$ & $\begin{array}{c}-1.0965 \\
(1.2219)\end{array}$ & $\begin{array}{c}-1.2610 \\
(1.2361)\end{array}$ & $\begin{array}{c}-0.8378 \\
(2.2394)\end{array}$ \\
\hline Observations & 503 & 498 & 490 & 2033 \\
\hline
\end{tabular}

Notes: For teenagers 12-13 years of age, see notes from Table 1. For teenagers 15-18 years of age, the percentile score on the Armed Forces Qualifications Test (AFQT) is used as the dependent variable. All models include controls for the following: child's age, child's race, child's birth order, the number of children in the family, mother's education, mother's labor force status at age 14, father's education, marital status of parents when child was 14, father's occupation at age 14, and religious affiliation. Standard errors are in parentheses. $+p<10, * p<.05, * * p<.01$. 
Table 5

Estimates of the Effect of Sibling Sex Composition on the Educational Achievement of Young Adults Between the Ages of 28 and 36

\begin{tabular}{|c|c|c|c|c|c|c|c|c|}
\hline \multirow[b]{2}{*}{ Sibling Measure } & \multicolumn{4}{|c|}{ Males } & \multicolumn{4}{|c|}{ Females } \\
\hline & $\begin{array}{l}\text { Years } \\
\text { Educ. }\end{array}$ & HS & $\mathrm{SC}$ & BA & $\begin{array}{l}\text { Years } \\
\text { Educ. }\end{array}$ & HS & SC & $\mathrm{BA}$ \\
\hline $\begin{array}{l}\text { White } \mathrm{x} \text { Proportion of } \\
\text { Siblings-Sisters }\end{array}$ & $\begin{array}{l}-0.2143 \\
(0.2039)\end{array}$ & $\begin{array}{c}0.0251 \\
(0.0340)\end{array}$ & $\begin{array}{c}-0.0712 \\
(0.0472)\end{array}$ & $\begin{array}{c}-0.0574 \\
(0.0666)\end{array}$ & $\begin{array}{c}0.0756 \\
(0.2023)\end{array}$ & $\begin{array}{c}0.0484 \\
(0.0313)\end{array}$ & $\begin{array}{l}-0.0066 \\
(0.0472)\end{array}$ & $\begin{array}{c}0.0106 \\
(0.0657)\end{array}$ \\
\hline $\begin{array}{l}\text { Black x Proportion of } \\
\text { Siblings-Sisters }\end{array}$ & $\begin{array}{l}0.7708 * * \\
(0.2789)\end{array}$ & $\begin{array}{l}0.1429^{* *} \\
(0.0465)\end{array}$ & $\begin{array}{l}0.1463^{*} \\
(0.0674)\end{array}$ & $\begin{array}{l}-0.0155 \\
(0.1080)\end{array}$ & $\begin{array}{c}-0.0591 \\
(0.2838)\end{array}$ & $\begin{array}{l}-0.0114 \\
(0.0439)\end{array}$ & $\begin{array}{c}0.0342 \\
(0.0680)\end{array}$ & $\begin{array}{l}-0.0823 \\
(0.0954)\end{array}$ \\
\hline $\begin{array}{l}\text { Hispanic x Proportion of } \\
\text { Siblings-Sisters }\end{array}$ & $\begin{array}{l}-0.1683 \\
(0.3513)\end{array}$ & $\begin{array}{l}-0.0666 \\
(0.0586)\end{array}$ & $\begin{array}{c}-0.0188 \\
(0.0881)\end{array}$ & $\begin{array}{c}0.1231 \\
(0.1347)\end{array}$ & $\begin{array}{c}0.1096 \\
(0.3450)\end{array}$ & $\begin{array}{c}0.0179 \\
(0.0533)\end{array}$ & $\begin{array}{c}0.0615 \\
(0.0852)\end{array}$ & $\begin{array}{l}-0.0616 \\
(0.1241)\end{array}$ \\
\hline $\begin{array}{l}\text { White } \mathrm{x} \text { Proportion of } \\
\text { Older Siblings-Sisters }\end{array}$ & $\begin{array}{l}-0.1160 \\
(0.1258)\end{array}$ & $\begin{array}{c}0.0306 \\
(0.0210)\end{array}$ & $\begin{array}{l}-0.0452 \\
(0.0294)\end{array}$ & $\begin{array}{c}-0.0689 \\
(0.0421)\end{array}$ & $\begin{array}{c}0.0292 \\
(0.1222)\end{array}$ & $\begin{array}{c}0.0125 \\
(0.0189)\end{array}$ & $\begin{array}{c}0.0038 \\
(0.0287)\end{array}$ & $\begin{array}{c}0.0332 \\
(0.0401)\end{array}$ \\
\hline $\begin{array}{l}\text { Black x Proportion of } \\
\text { Older Siblings-Sisters }\end{array}$ & $\begin{array}{c}0.1444 \\
(0.1643)\end{array}$ & $\begin{array}{c}0.0087 \\
(0.0274)\end{array}$ & $\begin{array}{c}0.0457 \\
(0.0396)\end{array}$ & $\begin{array}{c}0.0635 \\
(0.0629)\end{array}$ & $\begin{array}{c}0.2055 \\
(0.1622)\end{array}$ & $\begin{array}{c}0.0271 \\
(0.0251)\end{array}$ & $\begin{array}{c}0.0563 \\
(0.0391)\end{array}$ & $\begin{array}{l}-0.0281 \\
(0.0554)\end{array}$ \\
\hline $\begin{array}{l}\text { Hispanic x Proportion of } \\
\text { Older Siblings-Sisters }\end{array}$ & $\begin{array}{l}-0.1939 \\
(0.1978)\end{array}$ & $\begin{array}{l}-0.0296 \\
(0.0330)\end{array}$ & $\begin{array}{c}0.0552 \\
(0.0498)\end{array}$ & $\begin{array}{l}-0.0654 \\
(0.0762)\end{array}$ & $\begin{array}{l}-0.2812 \\
(0.1987)\end{array}$ & $\begin{array}{l}-0.0207 \\
(0.0307)\end{array}$ & $\begin{array}{c}0.0086 \\
(0.0495)\end{array}$ & $\begin{array}{l}-0.0830 \\
(0.0716)\end{array}$ \\
\hline White $\mathrm{x}$ Any Sisters & $\begin{array}{l}-0.1009 \\
(0.1207)\end{array}$ & $\begin{array}{r}-0.0030 \\
(0.0201)\end{array}$ & $\begin{array}{c}-0.0239 \\
(0.0278)\end{array}$ & $\begin{array}{l}-0.0357 \\
(0.0371)\end{array}$ & $\begin{array}{l}-0.0863 \\
(0.1189)\end{array}$ & $\begin{array}{c}0.0267 \\
(0.0184)\end{array}$ & $\begin{array}{l}-0.0304 \\
(0.0277)\end{array}$ & $\begin{array}{l}-0.0110 \\
(0.0371)\end{array}$ \\
\hline Black x Any Sisters & $\begin{array}{c}0.1679 \\
(0.1897)\end{array}$ & $\begin{array}{c}0.0350 \\
(0.0317)\end{array}$ & $\begin{array}{l}-0.0149 \\
(0.0456)\end{array}$ & $\begin{array}{c}0.0031 \\
(0.0689)\end{array}$ & $\begin{array}{l}0.3332+ \\
(0.1908)\end{array}$ & $\begin{array}{c}0.0424 \\
(0.0295)\end{array}$ & $\begin{array}{c}0.0511 \\
(0.0454)\end{array}$ & $\begin{array}{c}0.0448 \\
(0.0626)\end{array}$ \\
\hline Hispanic x Any Sisters & $\begin{array}{c}0.0675 \\
(0.2173)\end{array}$ & $\begin{array}{l}-0.0349 \\
(0.0363)\end{array}$ & $\begin{array}{c}0.0024 \\
(0.0531)\end{array}$ & $\begin{array}{l}0.1378+ \\
(0.0782)\end{array}$ & $\begin{array}{c}-0.2764 \\
(0.2185)\end{array}$ & $\begin{array}{l}-0.0631+ \\
(0.0338)\end{array}$ & $\begin{array}{c}0.0545 \\
(0.0522)\end{array}$ & $\begin{array}{c}0.0295 \\
(0.0754)\end{array}$ \\
\hline White $\mathrm{x}$ Any Older Sisters & $\begin{array}{l}-0.0740 \\
(0.1073)\end{array}$ & $\begin{array}{l}0.0297+ \\
(0.0179)\end{array}$ & $\begin{array}{l}-0.0388 \\
(0.0253)\end{array}$ & $\begin{array}{l}-0.0632+ \\
(0.0361)\end{array}$ & $\begin{array}{c}0.0393 \\
(0.1055)\end{array}$ & $\begin{array}{c}0.0268 \\
(0.0163)\end{array}$ & $\begin{array}{c}-0.0038 \\
(0.0249)\end{array}$ & $\begin{array}{c}0.0133 \\
(0.0351)\end{array}$ \\
\hline Black x Any Older Sisters & $\begin{array}{c}0.0942 \\
(0.1330)\end{array}$ & $\begin{array}{l}-0.0026 \\
(0.0222)\end{array}$ & $\begin{array}{c}0.0203 \\
(0.0322)\end{array}$ & $\begin{array}{c}0.0240 \\
(0.0521)\end{array}$ & $\begin{array}{l}0.2948^{*} \\
(0.1349)\end{array}$ & $\begin{array}{l}0.0439 * \\
(0.0209)\end{array}$ & $\begin{array}{c}0.0448 \\
(0.0325)\end{array}$ & $\begin{array}{c}-0.0067 \\
(0.0468)\end{array}$ \\
\hline $\begin{array}{l}\text { Hispanic x Any Older } \\
\text { Sisters }\end{array}$ & $\begin{array}{l}-0.0174 \\
(0.1598)\end{array}$ & $\begin{array}{l}-0.0192 \\
(0.0267)\end{array}$ & $\begin{array}{l}0.0691+ \\
(0.0400)\end{array}$ & $\begin{array}{l}-0.0778 \\
(0.0631)\end{array}$ & $\begin{array}{l}-0.2260 \\
(0.1555)\end{array}$ & $\begin{array}{l}-0.0128 \\
(0.0240)\end{array}$ & $\begin{array}{c}0.0090 \\
(0.0389)\end{array}$ & $\begin{array}{l}-0.0742 \\
(0.0575)\end{array}$ \\
\hline White $x$ Any Brothers & $\begin{array}{c}0.0279 \\
(0.1196)\end{array}$ & $\begin{array}{l}-0.0167 \\
(0.0200)\end{array}$ & $\begin{array}{c}0.0069 \\
(0.0275)\end{array}$ & $\begin{array}{c}0.0381 \\
(0.0385)\end{array}$ & $\begin{array}{c}0.0705 \\
(0.1233)\end{array}$ & $\begin{array}{c}-0.0049 \\
(0.0191)\end{array}$ & $\begin{array}{c}0.0182 \\
(0.0285)\end{array}$ & $\begin{array}{c}0.0068 \\
(0.0390)\end{array}$ \\
\hline Black x Any Brothers & $\begin{array}{c}0.0693 \\
(0.1854)\end{array}$ & $\begin{array}{c}-0.0034 \\
(0.0309)\end{array}$ & $\begin{array}{l}-0.0117 \\
(0.0436)\end{array}$ & $\begin{array}{c}0.0322 \\
(0.0652)\end{array}$ & $\begin{array}{c}0.1743 \\
(0.1924)\end{array}$ & $\begin{array}{c}-0.0154 \\
(0.0298)\end{array}$ & $\begin{array}{c}0.0081 \\
(0.0450)\end{array}$ & $\begin{array}{c}0.0704 \\
(0.0605)\end{array}$ \\
\hline Hispanic $x$ Any Brothers & $\begin{array}{l}-0.1813 \\
(0.2491)\end{array}$ & $\begin{array}{l}-0.0560 \\
(0.0416)\end{array}$ & $\begin{array}{c}0.0510 \\
(0.0592)\end{array}$ & $\begin{array}{c}0.0304 \\
(0.0889)\end{array}$ & $\begin{array}{c}-0.3151 \\
(0.2316)\end{array}$ & $\begin{array}{c}-0.0371 \\
(0.0358)\end{array}$ & $\begin{array}{l}-0.0742 \\
(0.0562)\end{array}$ & $\begin{array}{c}0.0184 \\
(0.0742)\end{array}$ \\
\hline $\begin{array}{l}\text { White } x \text { Any Older } \\
\text { Brothers }\end{array}$ & $\begin{array}{c}0.0465 \\
(0.1077)\end{array}$ & $\begin{array}{c}-0.0003 \\
(0.0180)\end{array}$ & $\begin{array}{l}-0.0010 \\
(0.0253)\end{array}$ & $\begin{array}{c}0.0303 \\
(0.0369)\end{array}$ & $\begin{array}{l}-0.0264 \\
(0.1045)\end{array}$ & $\begin{array}{l}-0.0037 \\
(0.0162)\end{array}$ & $\begin{array}{l}-0.0105 \\
(0.0245)\end{array}$ & $\begin{array}{c}0.0079 \\
(0.0342)\end{array}$ \\
\hline Black x Any Older Brothers & $\begin{array}{c}0.0194 \\
(0.1337)\end{array}$ & $\begin{array}{c}-0.0124 \\
(0.0223)\end{array}$ & $\begin{array}{l}-0.0044 \\
(0.0322)\end{array}$ & $\begin{array}{l}-0.0167 \\
(0.0512)\end{array}$ & $\begin{array}{l}0.2235+ \\
(0.1319)\end{array}$ & $\begin{array}{c}0.0211 \\
(0.0204)\end{array}$ & $\begin{array}{c}0.0165 \\
(0.0317)\end{array}$ & $\begin{array}{c}0.0140 \\
(0.0452)\end{array}$ \\
\hline $\begin{array}{l}\text { Hispanic x Any Older } \\
\text { Brothers }\end{array}$ & $\begin{array}{c}0.1594 \\
(0.1602)\end{array}$ & $\begin{array}{c}0.0043 \\
(0.0267)\end{array}$ & $\begin{array}{c}0.0121 \\
(0.0404)\end{array}$ & $\begin{array}{c}0.0123 \\
(0.0627)\end{array}$ & $\begin{array}{l}-0.0856 \\
(0.1576)\end{array}$ & $\begin{array}{c}0.0026 \\
(0.0244)\end{array}$ & $\begin{array}{l}-0.0512 \\
(0.0394)\end{array}$ & $\begin{array}{l}-0.0275 \\
(0.0573)\end{array}$ \\
\hline Observations & 4212 & 4212 & 3538 & 1600 & 4271 & 4271 & 3727 & 1864 \\
\hline
\end{tabular}

Notes: Six separate models are estimated for each dependent variable. Models differ according to which measure of sibling sex composition is used in the analysis. The dependent variables are as follows: Year Educ. Is the total number of completed years of education; HS is an indicator that person completed 12 years of schooling; SC is an indicator that person completed 13 to 15 years of schooling; and BA is an indicator that person completed 16 or more years of schooling. The appendix contains the complete results from a representative model. Standard errors are in parentheses. $+p<.10, * p<.05, * * p<.01$. 
Appendix A to Table 1 and Table 2

Variables Used in the Analysis of Child Cognitive Achievement

\begin{tabular}{|c|c|c|c|}
\hline \multirow[t]{3}{*}{ Variable } & \multicolumn{2}{|c|}{ Mean } & \multirow[t]{3}{*}{ Description } \\
\hline & Male & Female & \\
\hline & $7-8$ & $10-11$ & \\
\hline $\begin{array}{l}\text { Child Cognitive Tests } \\
\text { PIAT Math } \\
\text { PIAT Reading - Recognition } \\
\text { PIAT Reading - Comprehension }\end{array}$ & $\begin{array}{l}28.451 \\
30.757 \\
29.334\end{array}$ & $\begin{array}{l}44.455 \\
48.969 \\
44.882\end{array}$ & See text for description. \\
\hline $\begin{array}{l}\text { Sibling Sex Composition } \\
\text { Proportion of Siblings - Sisters } \\
\text { Any Sisters } \\
\text { Any Brothers }\end{array}$ & $\begin{array}{l}0.495 \\
0.652 \\
0.671\end{array}$ & $\begin{array}{l}0.473 \\
0.648 \\
0.715\end{array}$ & $\begin{array}{l}\text { Proportion of siblings is the proportion of siblings that are sisters, not } \\
\text { including child. }\end{array}$ \\
\hline $\begin{array}{l}\text { Child's Race } \\
\text { Black } \\
\text { Non-Black/Non-Hispanic } \\
\text { Hispanic }\end{array}$ & $\begin{array}{l}0.236 \\
0.451 \\
0.313\end{array}$ & $\begin{array}{l}0.219 \\
0.368 \\
0.395\end{array}$ & $\begin{array}{l}\text { A set of dummy variables indicating non-black/non-Hispanic, black, or } \\
\text { Hispanic. }\end{array}$ \\
\hline Child Birth Order & 0.494 & 0.604 & A dummy variable indicating first born. \\
\hline $\begin{array}{l}\text { Mother's Education } \\
12 \text { years } \\
13-15 \text { years } \\
16 \text { or more years }\end{array}$ & $\begin{array}{l}0.508 \\
0.171 \\
0.041\end{array}$ & $\begin{array}{l}0.478 \\
0.157 \\
0.022\end{array}$ & $\begin{array}{l}\text { Measured at the time of interview and in years of completed schooling. } \\
\text { Specified as a series of dummy variables indicating } 12 \text { years, } 13-15 \text { years, } \\
16 \text { or more years. }\end{array}$ \\
\hline Mother's AFQT Score & 30.801 & 26.364 & $\begin{array}{l}\text { Percentile score on the Armed Forces Qualifications Test. } \\
\text { Measured at the time of } 1980 \text { interview. }\end{array}$ \\
\hline Mother's Age & 29.083 & 30.102 & $\begin{array}{l}\text { Age at the time of interview and measured in years. Specified as a } \\
\text { quadratic. }\end{array}$ \\
\hline $\begin{array}{l}\text { Mother's Marital Status } \\
\text { Married } \\
\text { Separate/Divorced } \\
\text { Living with Partner }\end{array}$ & $\begin{array}{l}0.632 \\
0.167 \\
0.069\end{array}$ & $\begin{array}{l}0.557 \\
0.219 \\
0.074\end{array}$ & $\begin{array}{l}\text { A set of dummy variables indicating married, separated or divorce, or } \\
\text { living with partner at time of interview. Measured at time of interview. }\end{array}$ \\
\hline $\begin{array}{l}\text { Sibship Size } \\
\text { Three Children } \\
\text { Four Children } \\
\text { Five or More Children }\end{array}$ & $\begin{array}{l}0.351 \\
0.127 \\
0.054\end{array}$ & $\begin{array}{l}0.338 \\
0.137 \\
0.096\end{array}$ & $\begin{array}{l}\text { Measured at the time of interview and specified as a set of dummy } \\
\text { variables indicating } 3,4 \text {, or } 5 \text { or more children, including child. All } \\
\text { families in the sample have at least } 2 \text { children. }\end{array}$ \\
\hline Public Assistance & 0.251 & 0.292 & $\begin{array}{l}\text { A dummy variable indicating receipt of AFDC or SSI payments in year } \\
\text { prior to interview. }\end{array}$ \\
\hline $\begin{array}{c}\text { Year } \\
1988 \\
1990 \\
1992\end{array}$ & $\begin{array}{l}0.283 \\
0.258 \\
0.291\end{array}$ & $\begin{array}{l}0.224 \\
0.288 \\
0.386\end{array}$ & $\begin{array}{l}\text { A set of dummy variables indicating cognitive test year was } 1988,1990 \text {, } \\
\text { or } 1992 \text {. }\end{array}$ \\
\hline Timing of Births & 1.348 & 0.910 & Time between birth of next oldest sibling and child. \\
\hline Family Income & 24,526 & 25,546 & Total family income in years prior to interview. \\
\hline Missing Family Income & 0.138 & 0.134 & A dummy variable indicating missing family income. \\
\hline Number of Observations & 1,452 & 945 & \\
\hline
\end{tabular}


Appendix A to Table 3, Table 4, and Table 5

Variables Used in the Analysis of Teenage and Adult Educational Achievement

\begin{tabular}{|c|c|c|c|}
\hline \multirow[t]{3}{*}{ Variable } & \multicolumn{2}{|c|}{ Mean } & \multirow[t]{3}{*}{ Description } \\
\hline & Male & Female & \\
\hline & Teenage $15-18$ & Adult & \\
\hline AFQT Score & 36.436 & $\cdot$ & AFQT score as measured at time of 1980 interview. \\
\hline Years of Completed Education & - & 12.978 & Years of completed education as of May 1993. \\
\hline $\begin{array}{l}\text { Sibling Sex Composition } \\
\text { Proportion of Siblings -Sisters } \\
\text { Any Sisters } \\
\text { Any Brothers }\end{array}$ & $\begin{array}{l}0.362 \\
0.842 \\
0.842\end{array}$ & $\begin{array}{l}0.620 \\
0.840 \\
0.862\end{array}$ & $\begin{array}{l}\text { Proportion of siblings is the proportion of siblings that are sisters, } \\
\text { including respondent. }\end{array}$ \\
\hline Respondent's Age & 16.596 & 31.952 & $\begin{array}{l}\text { Age at time of interview }(1980,1993) \text { measured in years and specified } \\
\text { as a cubic function. }\end{array}$ \\
\hline $\begin{array}{l}\text { Respondent's Race } \\
\text { Black } \\
\text { Non-Black/Non-Hispanic } \\
\text { Hispanic }\end{array}$ & $\begin{array}{l}0.308 \\
0.502 \\
0.190\end{array}$ & $\begin{array}{l}0.297 \\
0.503 \\
0.200\end{array}$ & $\begin{array}{l}\text { A set of dummy variables indicating non-black/non-Hispanic, black, or } \\
\text { Hispanic. }\end{array}$ \\
\hline Respondent's Birth Order & 0.240 & 0.229 & A dummy variable indicating first born. \\
\hline Parental Marital Status at Age 14 & 0.667 & 0.679 & $\begin{array}{l}\text { A dummy variable indicating that respondent lived with both parents at } \\
\text { age } 14\end{array}$ \\
\hline $\begin{array}{l}\text { Mother's Education } \\
12 \text { years } \\
13-15 \text { years } \\
16 \text { or more years }\end{array}$ & $\begin{array}{l}0.386 \\
0.089 \\
0.074\end{array}$ & $\begin{array}{l}0.364 \\
0.086 \\
0.066\end{array}$ & $\begin{array}{l}\text { Measured at the time of } 1979 \text { interview and in years of completed } \\
\text { schooling. Specified as a series of dummy variables indicating } 12 \\
\text { years, 13-15 years, } 16 \text { or more years. }\end{array}$ \\
\hline $\begin{array}{l}\text { Mother's Labor Force } \\
\text { Participation at Age } 14\end{array}$ & 0.531 & 0.524 & $\begin{array}{l}\text { A dummy variable indicating mother figure of respondent worked when } \\
\text { respondent was age } 14 \text {. Measured at time of } 1979 \text { interview. }\end{array}$ \\
\hline $\begin{array}{l}\text { Father's Education } \\
12 \text { years } \\
13-15 \text { years } \\
16 \text { or more years }\end{array}$ & $\begin{array}{l}0.286 \\
0.094 \\
0.131\end{array}$ & $\begin{array}{l}0.286 \\
0.079 \\
0.112\end{array}$ & $\begin{array}{l}\text { Measured at the time of } 1979 \text { interview and in years of completed } \\
\text { schooling. Specified as a series of dummy variables indicating } 12 \\
\text { years, } 13-15 \text { years, or more than } 15 \text { years. }\end{array}$ \\
\hline Father's Occupation & 0.154 & 0.160 & $\begin{array}{l}\text { A dummy variable indicating that father figure's occupation when } \\
\text { respondent was age } 14 \text { was as a professional or manager. }\end{array}$ \\
\hline $\begin{array}{l}\text { Sibship Size } \\
\text { Two Children } \\
\text { Three Children } \\
\text { Four Children } \\
\text { Five Children } \\
\text { Six or More Children }\end{array}$ & $\begin{array}{l}0.224 \\
0.207 \\
0.137 \\
0.108 \\
0.194\end{array}$ & $\begin{array}{l}0.198 \\
0.195 \\
0.155 \\
0.101 \\
0.226\end{array}$ & $\begin{array}{l}\text { Measured at the time of interview and specified as a set of dummy } \\
\text { variables indicating } 2,3,4,5 \text {, or } 6 \text { or more children, not including } \\
\text { respondent. All families in the sample have at least } 2 \text { children. }\end{array}$ \\
\hline $\begin{array}{l}\text { Religious Affiliation } \\
\text { Catholic } \\
\text { Baptist }\end{array}$ & $\begin{array}{l}0.331 \\
0.297\end{array}$ & $\begin{array}{l}0.356 \\
0.299\end{array}$ & $\begin{array}{l}\text { A set of dummy variables indicating Catholic or Baptist religious } \\
\text { affiliation. }\end{array}$ \\
\hline Timing of Births & 2.204 & 2.195 & Time between birth of next oldest sibling and respondent. \\
\hline Number of Observations & 2075 & 4271 & \\
\hline
\end{tabular}

Notes: AFQT score is not used in the adult regressions, and years of education is not used in the teenage regressions. 
Appendix $B$ to Table 1 and Table 2

Estimates from Child Cognitive Achievement Regressions

\begin{tabular}{|c|c|c|c|c|c|c|c|c|}
\hline \multirow[b]{3}{*}{ Variable } & \multicolumn{4}{|c|}{ Tables 1,2 Model I MATH Age 7-8 } & \multicolumn{4}{|c|}{ Tables 1,2 Model 1 MATH Age $10-11$} \\
\hline & \multicolumn{2}{|c|}{ Males } & \multicolumn{2}{|c|}{ Females } & \multicolumn{2}{|c|}{ Males } & \multicolumn{2}{|c|}{ Females } \\
\hline & b & T-Stat & b & T-Stat & $\bar{b}$ & T-Stat & b & T-Stat \\
\hline Constant & 21.947 & 0.975 & 42.813 & 1.800 & 33.093 & 0.683 & 51.075 & 1.258 \\
\hline Black & -1.401 & -1.563 & -0.351 & -0.358 & -1.569 & -1.297 & -1.318 & -1.131 \\
\hline Hispanic & -2.392 & -2.595 & -1.596 & -1.767 & -0.699 & -0.586 & 0.166 & 0.160 \\
\hline Age Group 2 & 4.433 & 7.100 & 3.097 & 4.738 & 0.811 & 0.985 & 0.975 & 1.377 \\
\hline Age Group 3 & 7.570 & 11.803 & 7.889 & 12.166 & 3.559 & 4.403 & 2.425 & 3.200 \\
\hline Age Group 4 & 11.228 & 17.228 & 10.571 & 16.063 & 3.883 & 4.315 & 3.957 & 4.928 \\
\hline First Born & 0.403 & 0.750 & -0.063 & -0.115 & 1.022 & 1.470 & 1.328 & 2.080 \\
\hline Siblings $=3$ & -0.188 & -0.358 & -1.181 & -2.180 & 0.213 & 0.304 & 0.098 & 0.155 \\
\hline Siblings $=4$ & -0.970 & -1.266 & -1.651 & .2 .049 & 0.338 & 0.351 & -1.056 & -1.225 \\
\hline Siblings $=5$ or more & -2.554 & -2.270 & -3.434 & -3.377 & -0.573 & -0.444 & -2.959 & -2.825 \\
\hline Mother's Educ. $=12$ & 0.595 & 0.973 & 0.897 & 1.412 & 0.353 & 0.464 & 0.718 & 1.012 \\
\hline Mother's Educ. $=13-15$ & 1.434 & 1.669 & 1.596 & 1.910 & 0.978 & 0.872 & 0.176 & 0.178 \\
\hline Mother's Educ. $=16$ or more & 1.905 & 1.352 & 2.432 & 1.655 & 1.455 & 0.732 & 4.654 & 2.073 \\
\hline AFQT & 0.110 & 8.604 & 0.110 & 8.019 & 0.097 & 5.577 & 0.122 & 7.455 \\
\hline Mother's Age & 0.093 & 0.060 & -1.704 & -1.044 & 0.110 & 0.034 & -0.968 & -0.358 \\
\hline Mother's Age Squared & -0.003 & -0.117 & 0.032 & 1.149 & 0.004 & 0.069 & 0.018 & 0.399 \\
\hline Mother Married & -0.892 & -1.029 & 0.485 & 0.571 & -0.319 & -0.292 & 0.810 & 0.838 \\
\hline Mother Sep./Div. & -2.415 & -2.723 & -0.021 & -0.025 & -1.300 & -1.202 & -0.031 & -0.033 \\
\hline Mother Lives w/ Partner & -0.098 & -0.090 & 0.646 & 0.575 & 0.141 & 0.100 & 0.346 & 0.281 \\
\hline Year $=1988$ & -1.287 & -1.797 & -0.203 & -0.267 & 0.380 & 0.314 & 0.920 & 0.873 \\
\hline Year $=1990$ & -0.291 & -0.358 & -0.375 & -0.454 & 0.509 & 0.419 & -0.382 & -0.350 \\
\hline Year $=1992$ & -0.391 & -0.446 & 0.147 & 0.162 & 1.032 & 0.814 & 0.656 & 0.570 \\
\hline Public Assistance & -1.016 & -1.569 & 0.653 & 1.025 & -2.064 & -2.535 & -0.081 & -0.113 \\
\hline $\begin{array}{l}\text { White x Proportion Sibling - } \\
\text { Sisters }\end{array}$ & -0.133 & -0.167 & 0.018 & 0.022 & 1.218 & 1.085 & 0.439 & 0.422 \\
\hline $\begin{array}{l}\text { Black x Proportion Sibling - } \\
\text { Sisters }\end{array}$ & -0.900 & -0.782 & -0.081 & -0.062 & 0.182 & 0.113 & 1.381 & 0.922 \\
\hline $\begin{array}{l}\text { Hispanic x Proportion } \\
\text { Sibling - Sisters }\end{array}$ & -0.328 & -0.334 & 1.437 & 1.539 & -1.813 & -1.497 & -1.518 & -1.532 \\
\hline Adjusted R-Square & 0.312 & & 0.283 & & 0.183 & & 0.223 & \\
\hline Number of Observations & 1303 & & 1293 & & 856 & & 841 & \\
\hline
\end{tabular}

Notes: The age group dummy variables divide the two year period into four six-month intervals. 
Appendix B to Table 3, Table 4, and Table 5

Estimates from Teen and Young Adult Educational Achievement Regressions

\begin{tabular}{|c|c|c|c|c|c|c|c|c|}
\hline \multirow[b]{3}{*}{ Variable } & \multicolumn{4}{|c|}{ Tables, 4,5 Model 1 AFQT Age 15-18 } & \multicolumn{4}{|c|}{$\begin{array}{l}\text { Table } 5 \text { Model I COMPLETED } \\
\text { EDUCATION Age 28-36 }\end{array}$} \\
\hline & \multicolumn{2}{|c|}{ Males } & \multicolumn{2}{|c|}{ Females } & \multicolumn{2}{|c|}{ Males } & \multicolumn{2}{|c|}{ Females } \\
\hline & b & T-Stat & b & T-Stat & b & T-Stat & b & T-Stat \\
\hline Constant & -255.619 & -0.853 & 449.716 & 0.153 & -14.859 & -0.153 & -117.641 & -1.226 \\
\hline Black & -18.953 & -8.013 & -16.386 & -4.974 & -0.097 & -0.623 & 0.616 & 2.647 \\
\hline Hispanic & -10.347 & -3.669 & -11.060 & -2.957 & -0.184 & -1.023 & -0.164 & -0.622 \\
\hline Age Group 2 & 465.856 & 0.819 & -80.274 & -0.150 & - & - & - & - \\
\hline Age Group 3 & -269.540 & -0.781 & 49.924 & 0.154 & - & - & - & - \\
\hline Age Group 4 & 52.151 & 0.748 & -10.112 & -0.154 & - & - & - & - \\
\hline Age & - & - & - & - & 2.580 & 0.282 & 12.182 & 1.349 \\
\hline Age Squared & - & - & - & - & -0.821 & -0.287 & -3.808 & -1.348 \\
\hline Age Cubed & - & - & - & - & 0.088 & 0.294 & 0.396 & 1.348 \\
\hline First Born & 3.182 & 2.608 & 1.885 & 1.607 & 0.081 & 1.005 & -0.099 & -1.235 \\
\hline Siblings $=2$ & -2.877 & -1.663 & -1.077 & -0.668 & -0.207 & -1.808 & -0.015 & -0.134 \\
\hline Siblings $=3$ & -3.428 & -1.912 & -2.270 & -1.370 & -0.497 & -4.190 & -0.280 & -2.374 \\
\hline Siblings $=4$ & -7.165 & -3.573 & -2.200 & -1.255 & -0.684 & -5.241 & -0.318 & -2.530 \\
\hline Siblings $=5$ & -6.982 & -3.209 & -4.635 & -2.206 & -0.774 & -5.403 & -0.542 & -3.835 \\
\hline Siblings $=6$ or more & -8.755 & -4.341 & -3.977 & -2.161 & -0.971 & -7.444 & -0.594 & -4.667 \\
\hline Mother's Educ. $=12$ & 7.367 & 5.752 & 6.264 & 5.397 & 0.521 & 6.072 & 0.670 & 8.183 \\
\hline Mother's Educ. $=13-15$ & 12.271 & 6.073 & 9.100 & 4.700 & 1.113 & 8.142 & 1.234 & 9.382 \\
\hline Mother's Educ. $=16$ or more & 14.606 & 6.292 & 18.100 & 8.182 & 1.695 & 10.885 & 1.887 & 12.155 \\
\hline Missing Mother's Educ. & -0.162 & -0.075 & -1.358 & -0.617 & -0.510 & -3.767 & -0.136 & -0.926 \\
\hline Father's Educ. $=12$ & 6.404 & 4.754 & 5.960 & 4.901 & 0.351 & 3.934 & 0.483 & 5.616 \\
\hline Father's Educ. $=13-15$ & 11.061 & 5.654 & 6.928 & 3.665 & 0.972 & 7.175 & 0.857 & 6.410 \\
\hline Father's Educ $=16$ or more & 17.456 & 8.521 & 16.304 & 8.220 & 1.619 & 11.635 & 1.483 & 10.686 \\
\hline Missing Father's Educ. & -1.325 & -0.798 & 0.654 & 0.427 & -0.008 & -0.073 & -0.082 & -0.778 \\
\hline Parental Marital Status at Age 14 & 0.957 & 0.727 & 4.850 & 3.914 & 0.232 & 2.619 & 0.318 & 3.662 \\
\hline Mother's Labor Force Participation at Age 14 & 1.829 & 1.798 & 1.550 & 1.649 & 0.077 & 1.148 & 0.085 & 1.291 \\
\hline Missing Mother's Labor Force Participation & -5.646 & -1.827 & 5.332 & 1.471 & -0.121 & -0.579 & -0.015 & -0.065 \\
\hline Father's Occupation & 6.179 & 3.773 & 4.937 & 3.297 & 0.688 & 6.515 & 0.608 & 5.832 \\
\hline Missing Father's Occupation & 0.376 & 0.289 & 1.502 & 1.228 & -0.029 & -0.322 & 0.030 & 0.346 \\
\hline Catholic & 2.995 & 2.240 & 0.491 & 0.399 & 0.073 & 0.838 & 0.037 & 0.429 \\
\hline Baptist & -2.389 & -1.811 & -4.395 & -3.538 & -0.167 & -1.901 & -0.264 & -3.063 \\
\hline White $x$ Proportion Sibling - Sisters & 1.243 & 0.395 & 4.143 & 1.440 & -0.214 & -1.051 & 0.076 & 0.374 \\
\hline Black x Proportion Sibling - Sisters & 7.970 & 1.936 & 2.546 & 0.634 & 0.771 & 2.764 & -0.059 & -0.208 \\
\hline Hispanic x Proportion Sibling - Sisters & -2.117 & -0.383 & 0.453 & 0.093 & -0.168 & -0.479 & 0.110 & 0.318 \\
\hline Adjusted R-Square & 0.407 & & 0.407 & & 0.282 & & 0.244 & \\
\hline Number of Observations & 2075 & & 2033 & & 4212 & & 4271 & \\
\hline
\end{tabular}

Notes: The age group dummy variables divide the two year period into four six-month intervals. 